\title{
Two parallel systems: the political economy of enclosures and open fields on the plains of Västergötland, Western Sweden, 1805-65
}

\author{
LARS NYSTRÖM \& ERIK HALlBERG
}

KEYWORDS: enclosures, open fields, property rights, sunk costs.

\author{
JEL CODES: D23, N53, Q15, R32.
}

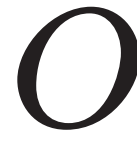

ne of the contradictions of enclosures is that they both promoted and threatened property rights. The reforms aimed at establishing modern, uncontested land ownership also undermined existing property rights. In many countries reform legislation required unanimity or a qualified majority of landowners in order for it to be implemented. However, in Sweden, a single landowner was enough to start an enclosure. This study takes developments in a plain region of Western Sweden as emblematic of the economic and institutional mechanisms of enclosures. The first villages in the area were enclosed in 1805, the last in 1865. The fact that the two systems coexisted for six decades in this area provides a "historic laboratory" for the reconstruction of technological, productive and land value changes. One important research question relates to the slow advance of enclosures: how could open fields have survived for so long when every landowner could veto their very existence? Results show that up until the early 1850s, enclosed land offered few advantages for local farmers. This system was not more productive than open fields, nor did the reform stimulate the adoption of innovations such as convertible husbandry or iron ploughs. Still, in the long run, strong legal imperatives made enclosures almost inevitable. Consequently, the long period of parallel existence can be understood as the outcome of a situation in which the open fields still possessed an economic advantage, while enclosures enjoyed an institutional advantage. 


\section{Dos sistemas paralelos: la economía política de cercamientos y campos abiertos en los llanos de Vestrogotia, Suecia occidental, 1805-1865}

\section{PALABRAS CLAVE: cercamientos, campos abiertos, derechos de propiedad, costes hundidos.}

\section{CÓDIGOS JEL: D23, N53, Q15, R32.}

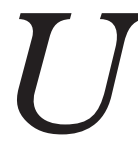

na de las contradicciones de los cercamientos es que promovieron, al tiempo que amenazaron, los derechos de la propiedad. El objetivo de las reformas era establecer una propiedad de la tierra moderna y absoluta, proyecto que conllevaba la demolición de los derechos de la propiedad existentes. En muchos países la reforma requirió el apoyo de una mayoría cualificada de terratenientes. En Suecia, sin embargo, cada propietario podía iniciar un cercamiento.

Este artículo estudia los mecanismos económicos e institucionales de los cercamientos en un área de llanuras del oeste de Suecia. Los primeros cercamientos en esta zona fueron realizados en 1805 y los últimos en 1865. El hecho de que los dos sistemas coexistiesen durante seis décadas nos permite reconstruir la tecnología, la producción y el valor de la tierra dentro de los dos regímenes, usando esa zona como un «laboratorio histórico" de la reforma. El lento avance de los cercamientos constituye un problema clave de la investigación. ¿Cómo pudieron perdurar tanto tiempo los campos abiertos cuando cada terrateniente podía vetar su existencia?

Los resultados indican que hasta principios de la década de 1850 los cercamientos ofrecían pocas ventajas económicas para los agricultores de la zona. Aun así, los fuertes imperativos legales hicieron que los cercamientos a largo plazo fueran inevitables. El amplio periodo de coexistencia de los dos sistemas estuvo, por tanto, marcado por una situación en la cual los campos abiertos todavía poseían una ventaja económica mientras que los cercamientos una ventaja institucional.

Received: 2017-02-01 - Revised: 2017-11-03 - Accepted: 2017-11-07

Lars Nyström [orcid.orgl 0000-0002-4640-935X] is a senior lecturer in History at the Department of Historical Studies, University of Gothenburg, Sweden. Address: Institutionen för historiska studier, Box 200, 40530 Göteborg (Sweden).E-mail: lars.nystrom@history.gu.se

Erik Hallberg [orcid.org/0000-0003-3187-0052] is a researcher in History at the Department of Historical Studies, University of Gothenburg, Sweden. Address: Institutionen för historiska studier, Box 200, 40530 Göteborg (Sweden).E-mail: erik.hallberg@history.gu.se 


\section{INTRODUCTION}

In every process of enclosure, there is a period of transition during which enclosed land and open fields coexist as two parallel systems. In England, this period lasted for several hundred years, from the 14th to well into the 19th century. In Sweden, it was shorter. Although the privatisation of the commons had already begun by the storskifte reform (17491827), it was not until the ordinances of enskifte (1803-27) and the subsequent laga skifte (1827-) that enclosures began to affect open fields. Roughly 60 years after the initiation of these reforms, nearly all of the villages in the arable districts of southern and western Sweden had been enclosed; a few decades later most villages and hamlets in the eastern provinces also had passed through the reform.

In a long-term perspective, this was indeed a rapid transition. Nevertheless, from the perspective of the time, it stretched over a considerable period of time. In many districts, the two systems existed side-by-side for two or even three generations of farmers. In this article, the situation in an area on the central plains of the province of Västergötland, in western Sweden, will be examined more closely. Prior to enclosure, the area was dominated by large villages with extensive open fields, covering almost all of the land. The first enclosure in the area was initiated shortly after the adoption of the enskifte legislation for this province in 1804 . It was, however, not until the 1860s that the last villages entered the process of enclosure. During this period of transition, the plains could be described as a mosaic of enclosed and open-field land where systems of farming differed from one neighbouring village to another. This situation leads to several observations.

First, the parallel existence of enclosed and open-field land systems actually makes it possible for us as historians to compare the two regimes. In this study, the plains area in Västergötland, where conditions (for example, soil, climate, market possibilities, and farming traditions) differed very little from one village to another, will be used as a "historical laboratory" of enclosure and open-field systems. Seeds, livestock, aspects of farming technology, and land prices will be measured in order to isolate the effects of enclosure on agrarian development.

A second and equally central point is that contemporary farmers could realistically have made a similar comparison to the one in this study. Since enclosed and open-field villages lay side-by-side on the plains for so many years, the consequences of the reform were obvious for everyone, given that peasants from both property regimes met at church on Sundays or as relatives and friends. Farmers must thus have been fully able to assess the advantages and disadvantages of the two systems, as well as judge which of the two systems suited them best. 
MAP 1

The area of research

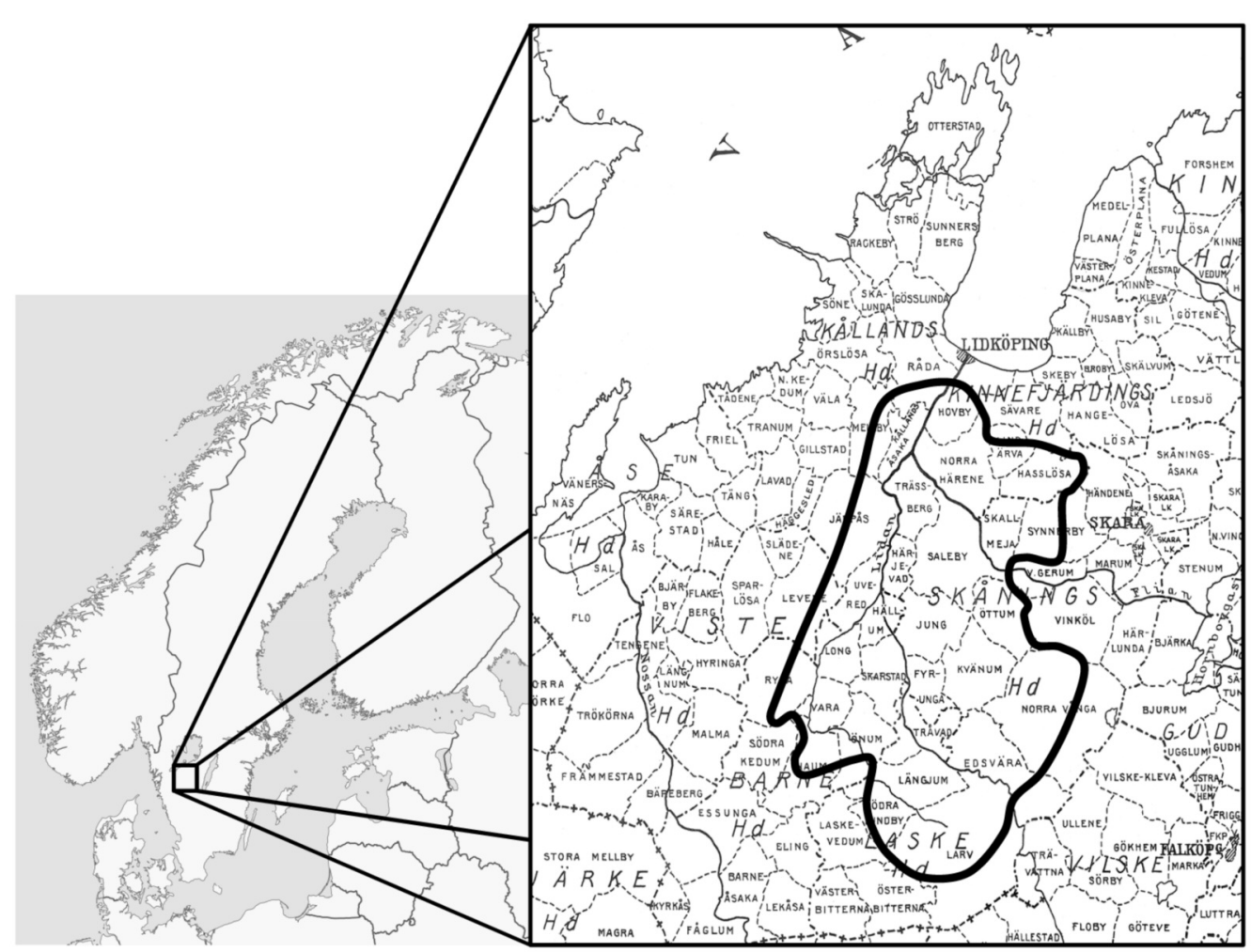

This latter situation gives rise to third and final point, namely that the parallel existence of these two agricultural systems requires an explanation in itself. In a perfect situation in which farmers and landowners had access to reliable information about the systems and were able to make a rational choice, the most efficient one would soon prevail. Arguably, farmers were reasonably well-informed. The foundation of this investigation must also rest on the idea that they acted rationally. If enclosures were the best option, as claimed both by the experts of that time and by most later agrarian historians, landowners would rapidly opt for this solution. Why, then, did the situation of parallel existence last for so long?

\section{THE REVERSED INSTITUTIONAL AND SOCIAL SETTING}

One objection to the argument above is as follows: the parties involved might indeed have been rational, but they might not have been able to choose a course of action freely. In 
the real world, their decisions were bound by institutional, political and cultural constraints, and they also had to consider the costs of the reform. Furthermore, one group might have considered enclosure to be rational (for example, the great landowners), but not others (for example, the landless population). From this perspective, the systems' concurrent existence could be explained as the result of institutional imperfections (using an institutional approach) or of an on-going class struggle (employing a materialistic approach). In both cases, the situation in England can provide illustrative examples ${ }^{1}$.

The debate about conflicting interests in the British enclosure process comprises one of the main threads of social history. According to Robert Allen's $(1982,1992)$ investigations into enclosures in the Midlands in the $18^{\text {th }}$ and $19^{\text {th }}$ centuries, these reforms mainly resulted in a redistribution of agrarian incomes, and not so much of an increase in agrarian production ${ }^{2}$. Others would disagree, but few would claim that commoners and copyholders favoured the reform. Regardless of whether enclosure was a plain enough case of class robbery or not, there is well-documented resistance towards the reform, an element that can provide at least part of an explanation to the long period of open-field-enclosure coexistence ${ }^{3}$.

At the same time, formal institutions hindered a rapid transition. Before the introduction of parliamentary enclosure in the $18^{\text {th }}$ century, unanimity among landowners was required in order to enclose open fields. Among others, McCloskey (1975: 127-33) pointed out how this stipulation made enclosures extremely complicated; often bribes or threats often seem to have been necessitated in order to deal with reluctant stakeholders ${ }^{4}$. For parliamentary enclosures, the support required was reduced to owners representing $75 \%$ or $80 \%$ of the land. Even in this situation, however, the process was difficult and expensive ${ }^{5}$. The fact that landowners were willing to endure these high costs of transition most likely reflects a situation in which considerably higher returns from the land could be expected in the enclosed regime. With easier and cheaper legal procedures, these gains

1. The Swedish development will in this paper mainly be contrasted to the English. For an introduction to the wider European discussion on common fields and enclosures, see RENES (2010), DYER, Toen and Williamson (2018) and Grüne, HÜBNER and Siegl (2016).

2. See also criticism in CLARK (1998).

3. Quotation by THOMPSON (1963: 218). CARTER (1998) offers convincing evidence from Middlesex, as well as a useful historiographical overview. See also, for example, YeLLING (1977: 47-58, 70), HEAley (2016) and, as a contrast, SHAW-TAYLOR (2001).

4. See also Dahlman (1980: 183-87), Chapman and SEeliger (2001: 25-6) and the discussion on France in Grantham (1980).

5. Turner (1980: 153-57); DAhlman (1980: 180-81); Yelling (1977: chapter 4); Chapman and SEELIGER (2001: 26-7), who in this context stress the importance of informal and piecemeal enclosures. 
would have been even higher and, as Turner (1980: 169-70) suggested, enclosures would most likely also have been initiated earlier. Thus, it appears the English institutional situation enabled the open-field system to survive longer than was economically desirable (at least from a large-landowner perspective).

The Swedish case makes an interesting contrast. The enskifte legislation (1803-27) gave every landowner the right to individual enclosure, that is, the removal of his share of the open fields into one single piece of land ${ }^{6}$. In several ways, it also advocated general enclosures: the enclosure of the whole village.

In Laga skifte (1827-), this institutional situation was taken one step further to absolute priority of enclosure: If one single landowner wanted to enclose his property, the whole village had to be enclosed, regardless of the opinion of the other stakeholders. Compared to pre-parliamentary enclosure in England, a reversed institutional situation was established in Sweden: unanimity among landowners was in fact required in order to maintain the open fields.

At the same time, the social setting in the two countries differed. In many respects, Sweden represents Robert Allen's (1992: 303-11) lost yeoman alternative in English agrarian history. Through several reforms, the peasantry was strengthened and advanced economically and politically throughout the $18^{\text {th }}$ and $19^{\text {th }}$ centuries. While in England, land passed from the peasantry to the gentry, in Sweden, the state and nobility sold off much of their land to the peasants ${ }^{7}$.

Taking all of these developments into consideration, there has been a strong tendency in recent Swedish historiography to weave the advancement of the peasantry and advancement of enclosures into one single story of success ${ }^{8}$. As peasants are seen as rational and successful, and enclosures are also understood as rational and successful, it has been natural to associate the latter with the former. In contrast to an older tradition of research where agrarian modernisation (often under the influence of the English case) was seen as a "top-down" process driven by enlightened gentlemen-farmers and the state more

6. For a brief history of the legal framework of the reforms in English, see GADD (2011: 149-54).

7. See WINBERG (1990) or GADD (2011: 134-38) for an overview.

8. See for example Wiking-Faria (2009), Svensson (2006), SVEnsSon (2005), and PetTersson (2003). The new paradigm was established by, among others, GADD (1983) and PETTERsson (1983) in accordance with a general re-interpretation of Swedish agrarian history discussed in WINBERG (1990). 
or less against the will of the peasantry ${ }^{9}$, agrarian revolution and enclosures are now to an increasing degree understood as a "bottom-up" process driven by an advancing peasantry. One recurrent argument in this context is that free-holders actually initiated most of the enclosures.

From the perspective of this study, however, it is more remarkable that it took so long before free-holders actually did pursue enclosure. In most Swedish villages, there were only free-holders and, consequently, only free-holders could start the reform. Given the situation in which every landowner since the early $19^{\text {th }}$ century had the right to enclose his land, why did it take 40 to 50 years before the great wave of reform swept across the country $^{10}$ ? In other words, if free-holders acted rationally, if -as is generally assumed- enclosure meant a great advance, how could open fields survive for so long in a situation in which every landowner had a veto against their continued existence?

\section{AREA OF RESEARCH}

In the following sections, results from a study on enclosure and open-field farming on the central plains ofVästergötland will be presented. From a historiographical point of view, this is classic ground in Swedish research. It was the main area of study in Carl-Johan Gadds' (1983) Färn och potatis, ("Iron and potatoes"), considered by many to be the most important Swedish in-depth study of the agricultural revolution. In his analysis, farming technology, crop rotations, and social and demographical developments were carefully investigated. Enclosures were also discussed, but mainly on a hypothetical level. In fact, Gadd did not empirically examine enclosures on the Västergötland plains.

Yet if we want to contrast the two systems, it is hard to find any better area to research. Before enclosure, virtually all land was used as open fields. As grazing was integrated between the villages, these fields sometimes stretched for many miles. The large-scale character of the agrarian landscape was further strengthened by the sizeable villages that in some cases consisted of up to 80 individual farmsteads. In such an area, enclosures meant a total remodelling of the whole agrarian landscape. The fact that the villages were so large is also interesting from an institutional point of view. With so many stakeholders, the absolute priority of enclosure was really put to the test.

9. See for example HecksCHER (1941) and ÅBERG (1953).

10. Regarding the regional chronology of the reform, see HELMFRID (1961). 


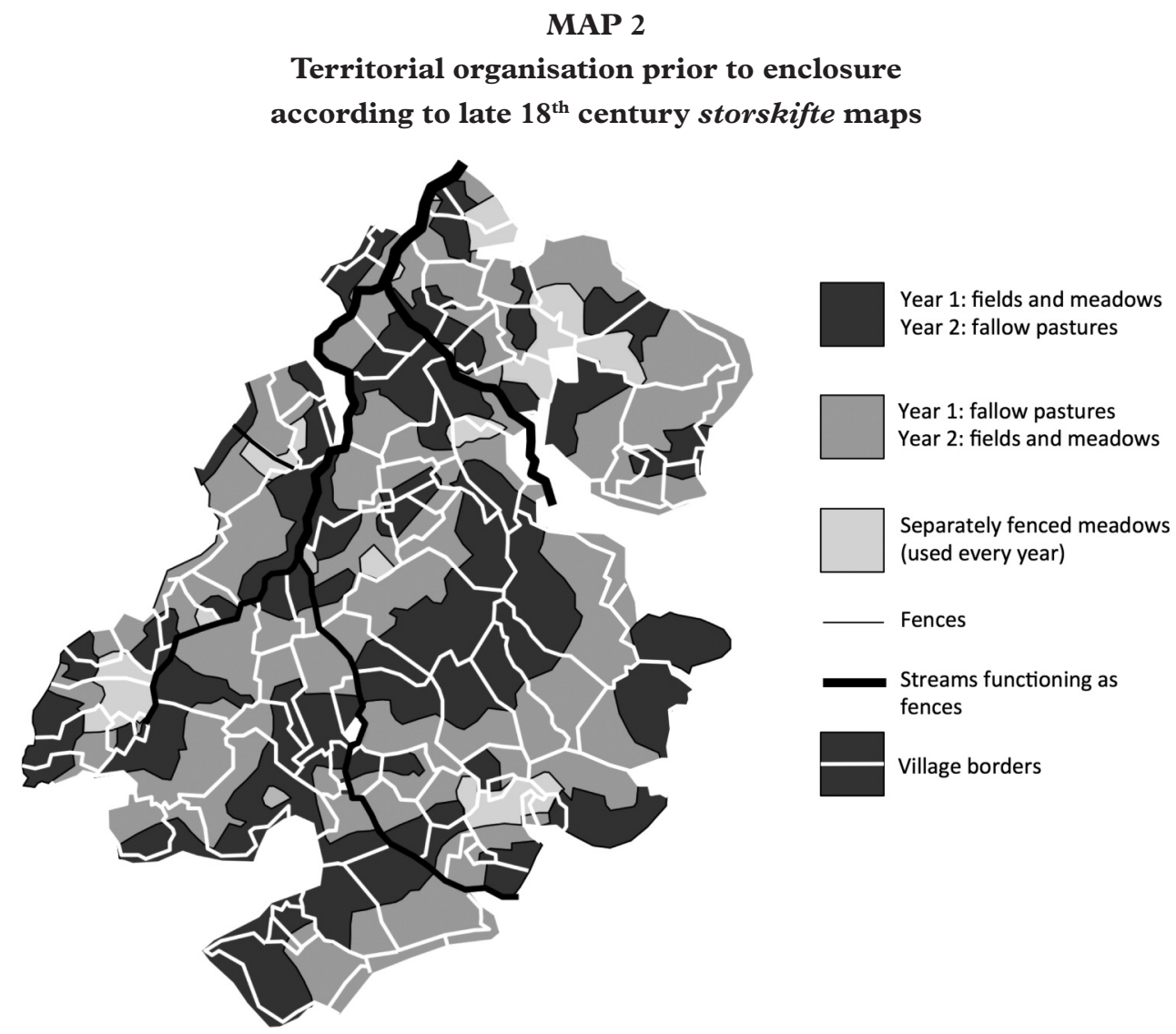

The distance from north to the south on the map is 36 kilometres.

Sources: the map is compiled from the storskifte reform maps of 85 individual villages. A few older and newer cadastral maps have also been consulted. At a limited number of spots the territorial organisation has been deduced from settlement structure combined with field patterns in surrounding areas. White areas lack sufficient data.

Traditional farming on the plains was based on a two-field system (see maps 2 and 4$)^{11}$. Every year, half of the land was used for crops or meadows. The other half lay fallow and was used as common pasture. The farmsteads were clustered along the wooden fence that separated the two halves. One year, cattle were let out to graze on one side of the fence, and the next year on the other. The fact that there were only two fields, that there was no separately fenced waste, and also that grazing was co-ordinated between the villages, reduced the need for fences to a minimum. This was important since the area virtually lacked all recourse to wood.

11. The regional farming system is also discussed in GADD (1983: 206-18) and JANSSON (1998: 121-23). 


\section{MAP 3}

\section{Geographical chronology of enclosures (enskifte or laga skifte)}

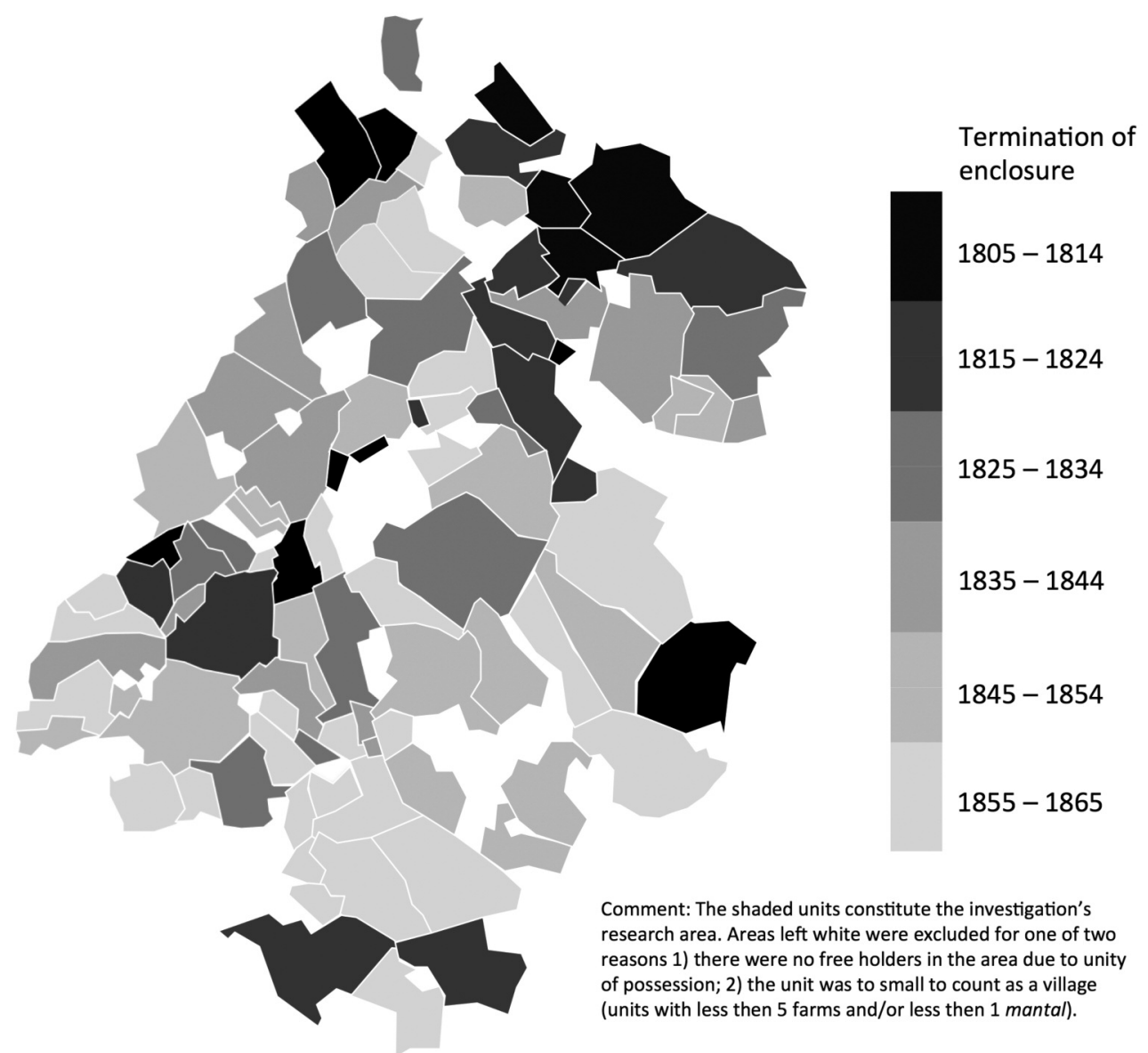

Sources: enskifte and laga skifte reform acts.

During the $16^{\text {th }}$ and $17^{\text {th }}$ centuries, this farming regime was a significant site for animal production, but gradually, as the population grew, grain became the main specialisation. By the 1780 s, exports of cereals was mentioned as the only way for local farmers to get access to markets. Surplus production was largely sold to the ironmaking regions of Bergslagen and Värmland on the other side of Lake Vänern. Cows, pigs, and sheep were kept for local needs. However, their numbers declined steadily over time.

One crucial problem in this context was the growing shortage of fodder. As more and more land was reclaimed during the $18^{\text {th }}$ and $19^{\text {th }}$ centuries, the area covered with mead- 


\section{MAP 4}

\section{Storskifte map of Fyrunga in 1785}

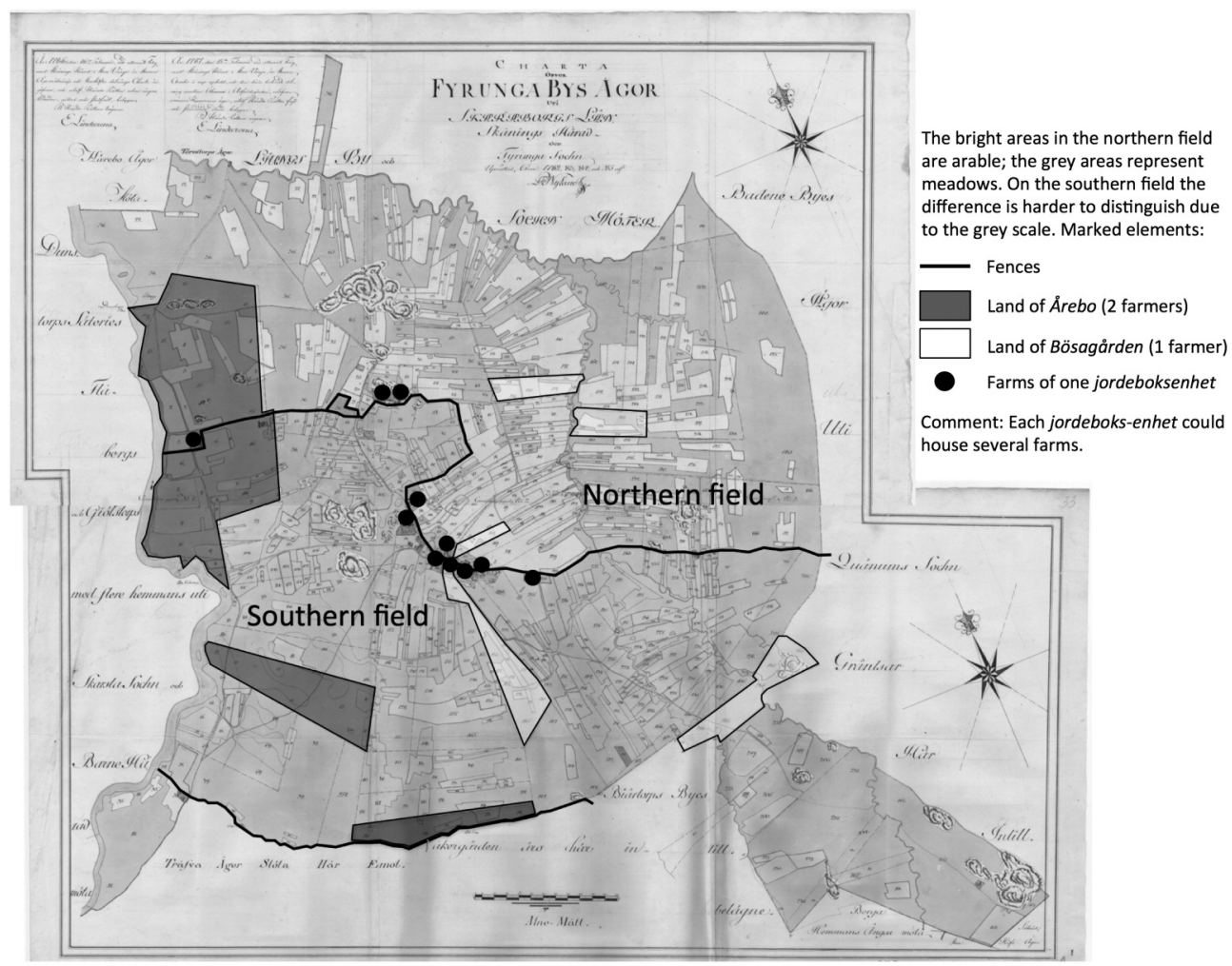

Source: Digital archive of Lantmäteristyrelsen.

ows was correspondingly reduced. With fewer meadows, it became harder to feed the cattle during the winter; and if the number of cattle was reduced, there were fewer sources of traction power and manure for the fields -a classic dilemma of traditional farming. The management of this situation constitutes a main thread in Carl Johan Gadd's research into the region. In contrast, the scattering of land -often identified as one of the drawbacks of the open-field system- seems to have been less of a problem. During the Storskifte land reform in the late $18^{\text {th }}$ century, the number of strips belonging to each farm was substantially reduced; in many cases, to just three or four (see Map 4). However, as villages were large, farmers often had to walk considerable distances to reach their land.

The first enclosure in this study's area of research took place in Åsaka in 1805. Figure 1 and Map 3 offers an overview of the chronology of the subsequent acts of enskifte 


\section{MAP 5}

Laga skifte of Fyrunga village in 1847

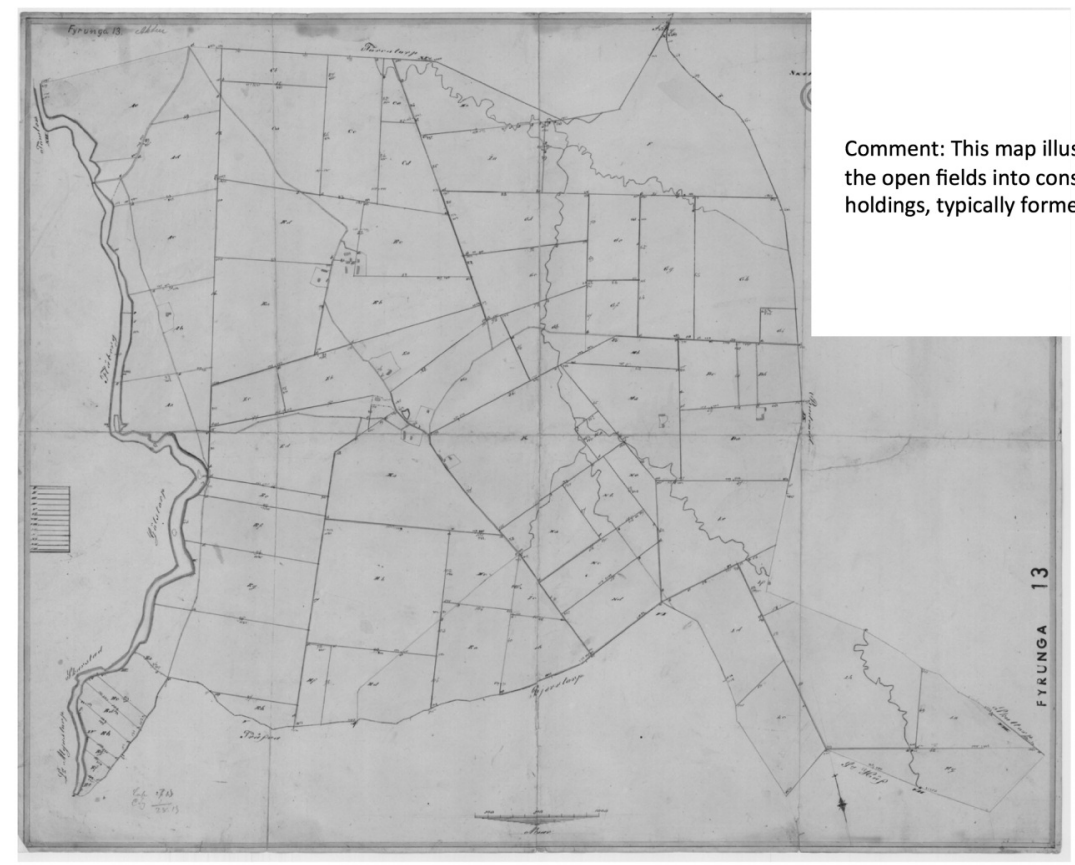

Source: enclosure act 16-FYR-13, digital archive of Lantmäterimyndigheten.

and laga skifte. The figure is based on the time when each enclosure was initiated, the map depicts its conclusion. As seen in the figure, the early 1850 s can be identified as the most intensive period in terms of new applications. At this phase, almost half a century had passed since the introduction of enskifte reform in 1804, though it also must be noted that the more radical laga skifte ordinance in 1827 was more recent. Legal enclosure processes often stretched over several years, sometime more than a decade. It was not until the termination of enclosure in Längjum in 1865 that the process in the area was finally concluded. 
FIGURE 1

The chronology of enclosure in the research area: number of mantal entering the process per year

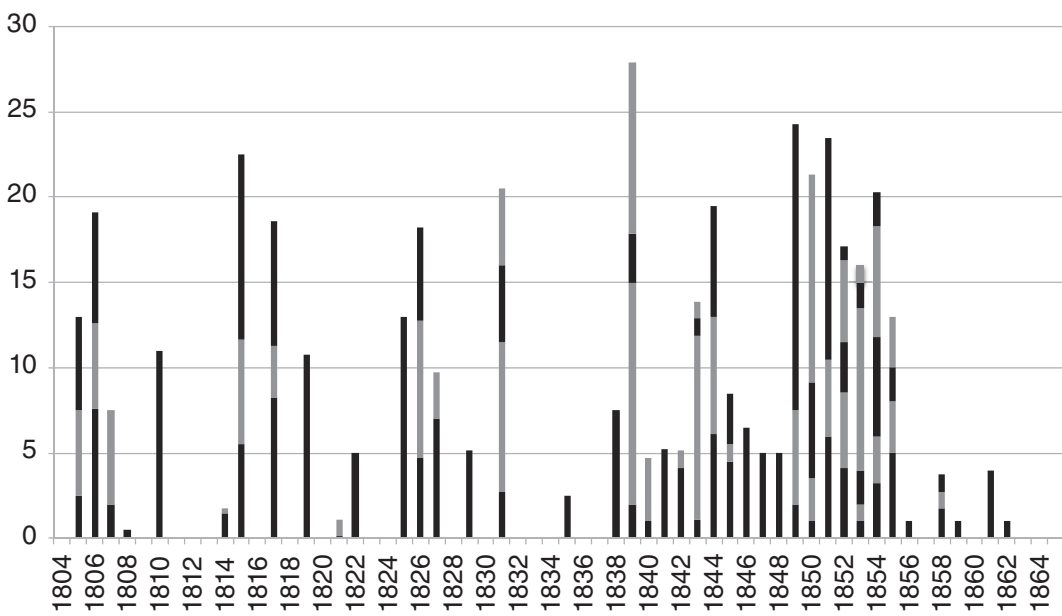

Note: village units of 1 mantal and 5 farmsteads (in the case of individual enskiften smaller units part of large enough villages are also included).

Sources: cadastral act registers; enclosure acts (accessible via the Swedish Authority of Land Surveying, www.lantmateriet.se).

\section{METHODOLOGICAL CONSIDERATIONS}

The following analysis is based on probate inventories from free-holders on enclosed and open-field land, records of land transactions, and enclosure acts from 88 villages. The probate inventories list tools, animals, and seeds, which enable us to reconstruct agricultural practices within the two systems in some detail. Records of land sales are used to reconstruct market prices of enclosed and open-field land, which reflects both its production potential and buyers' interpretation of the two systems. Enclosure acts make it possible to establish the time of enclosure for each farm being observed.

In order to be able to take the size of the farmsteads into account, quantities of land are measured in mantal units. These comprised the official Swedish measurement of land during the period of investigation and were used primarily for taxation purposes as well as in some situations during enclosure. The unit of 0.25 mantal used in the present investigation equals the median size of a farmstead throughout the period studied. On average a 0.25 mantal farm encompassed over 28 hectares of land ${ }^{12}$.

12. This area is calculated from the basis of geocoding of the villages of investigation. 
The mantal appears in most documents regarding farms, and has also the strategic advantage of being stable over time. If, for example, a farm of 0.25 mantal was divided into two separate farmsteads of equal size, the result was two units of 0.125 mantal each. The fact that the total mantal of specific areas remained unchanged throughout the period in question enables us to calculate changes in production and land prices over time. At the same time, however, it must also be stressed that it is a rather rough measurement. The "real size" of the mantal, as measured in for example land value or seeds, could vary considerably. This disparity is also reflected in a high level of statistical variation in the material used in the investigation ${ }^{13}$. Consequently, an ample number of observations are required in order to make results statistically reliable. Crosschecks have been done on the collected data, using observations preceding or at the very beginning of the process of enclosure, to ensure that early-enclosed land was not, on average, in the possession of more/less resources per mantal than land enclosed later. No such tendency could be discerned $^{14}$.

In total, the study is based on evidence from 2,041 records of land sales from 180462 and 1,342 probate inventories from 1795-1869. The most reliable results are from the period from the early 1830 s to the late 1840 s when there are plenty of both enclosed and open-field land observations. Regarding early enclosed and late open-field land there are fewer sources. Still, with only one exception, no cohorts with less than 20 observations are used in the investigation. All differences between enclosed and open-field land discussed in the text are statistically significant at the 0.05 level unless otherwise stated. ${ }^{15}$

\section{LAND PRICES}

The prices of enclosed and open-field land are useful as indicators of the development within the two systems ${ }^{16}$. To a certain extent, market prices of these types of land should

13. Some examples of coefficients of variation: 0.37 (seeds/mantal open-fields 1815-24); 0.48 (seeds/mantal enclosed land 1850-59); 0.49 (land price/mantal open-fields 1815-24); 0.73 (land price/mantal enclosed land 1850-59).

14. Land entering the process before the start the continuous wave of enclosure after 1837 (Figure 1) has been compared to land entering the process after this year using 242 probate inventories preceding enclosures (1795-1804) and 260 registered land sales at the very beginning of the process (1804-13). Seeds in weighed barrels (Figure 4) were at 9.13 for the early cohort and 8.91 for the late cohort. Correlation time of enclosure-seeds was at -0.04. Possession of livestock units (after GADD, 1983: 114) 10.19/10.29, correlation 0.07; land prices (in riksdaler riksgäld) 906/915, correlation -0.02.

15. Statistical significance has been tested using unpaired, two-tailed t-tests.

16. MCCloskey (1975: 151-59), Yelling (1977: 210-13), ALLEN (1992: chapter 9), and ClARK (1998) have discussed enclosures' effects on rents in England in a similar manner. By using land 
reflect the effectiveness of each system. If agricultural productivity rose as a result of enclosures, then the price of enclosed land should rise as well.

At the same time, however, other factors must be taken into account, such as expectations of future returns from the land. If considerable gains could be expected from enclosure, this might also affect prices on unenclosed land. Another aspect of potential importance is the reform's impact on agricultural capital. In practice, an enclosure led to the substantial destruction of capital in the form of buildings and fences, a capital that had to be reconstructed. Therefore, at least during a transition period, enclosed land might actually have been traded at lower prices than unenclosed land, even if its production potentials were better.

In a long-term perspective, other possible scenarios also emerge. If farmers began to regard enclosure as inevitable, it is conceivable that existing capital that was bound up in the old village structure actually began to be regarded as worthless -a kind of "sunk capital". Therefore, it can be imagined that unenclosed land was traded at a lower price -even in a situation in which actual productivity was similar. Thus, on the basis of a price index for enclosed and open-field land, the peasants' understanding of the two systems may also be discussed.

Figure 2 presents the overall price development for land for the period studied.

It is notable how the price of land started to rise precisely in the period of the most intensive enclosures in the 1840s and early 1850s. In the following decade (which also was the time of the Crimean war and the start of massive exports of oats from Western Sweden to England), they exploded.

What was the role of enclosure in this development? In Figure 3, the average prices for open-field and enclosed land from 1818-53 are presented.

In the beginning of the period studied, enclosed land was not more attractive on the property market than open-field land; instead, the tendency is the opposite. This pattern, however, rapidly changes from the mid-1830s. For the rest of the period of study, enclosed land was traded at substantially higher prices than open-field land.

prices, the problematic issue of income distribution among landowners and farmers is avoided. 
FIGURE 2

Overall price (arithmetic mean) development for unprivileged land in the research area, 1804-62. Riksdaler riksgäld per $1 / 4$ mantal (median farm size)

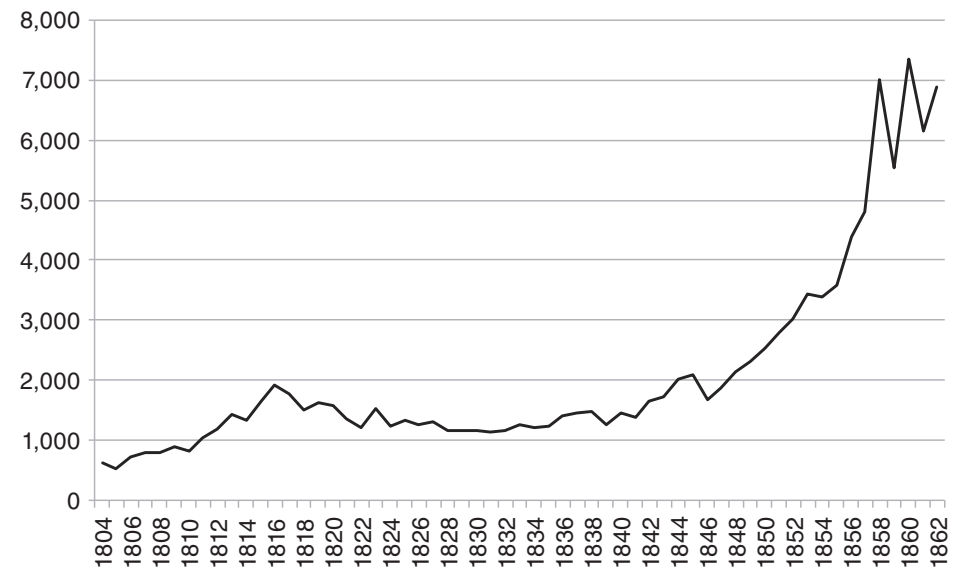

Note: transactions of $1 / 24<1$ mantal.

Sources: register of land sales (uppbudslängder) in Skåning, Barne, Kålland, Kinnefjärding and Laske hundreds. Regional Archives of Gothenburg (Riksarkivet i Göteborg).

FIGURE 3

Average prices (arithmetic mean) of enclosed and open-field land in the research area, 1818-53. Riksdaler riksgäld per $1 / 4$ mantal of unprivileged land

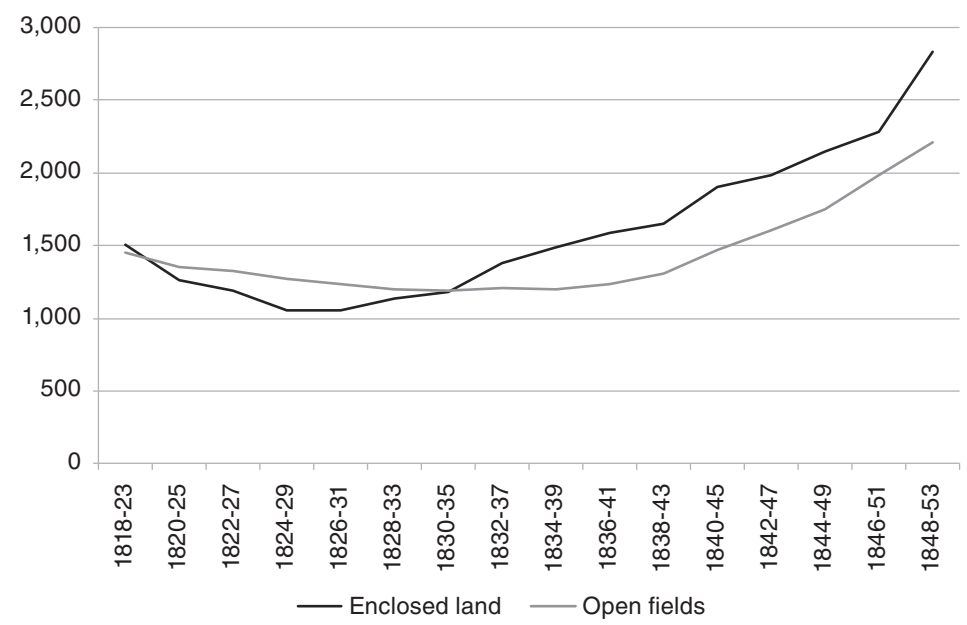

Notes: transactions of $1 / 24<1$ mantal skatte- and kronoskatte land. Exclusions include: transactions where the size in mantal could not be established; land under the process of enclosure (defined here as from its initiation until three years after its legal termination); transactions involving benefits in kind to the former owners (undantag) or the covering of their debts. The differences between the two categories of land from 1826-31, 1834-39/1844-49 and 1848-53 are statistically significant at the 0.05 level.

Sources: see Figure 2. 
The previous discussion points to one possible explanation for the low prices paid for enclosed land during the early period of study, namely that part of the old "open-field bound" farm capital, which was eliminated by enclosure, had not yet been fully displaced by new inversions. One important factor in this context was probably that the 1820 s were a difficult period for European farmers. The blissful years of the Napoleonic wars were over, and both grain prices and land prices went down. This economic shift made investments more risky and capital more difficult to access. It is reasonable to assume that this development affected newly enclosed land, which urgently required large investments, particularly hard.

The fact that enclosed land during this period was traded at a reduced price offers at least part of an explanation for the "parallel existence" and slow advance of the enclosed regime. It is hardly surprising that most farmers chose not to opt for enclosure if the expected outcomes of such a project did not include an increase in the value of the farm. If enclosures were to be economically justified, prices on enclosed land needed to be higher than on open-field land. Similarly, it is also logical that considerably more enclosures occurred during the later phase of the study, when enclosed land had been up-valued by the market and was traded at substantially higher prices than open-field land.

An important question in this context is what caused this growing divergence. One possibility is, of course, that this shift reflected developments on the ground. In this scenario, the enclosed system now effectively outcompeted the open-field regime in terms of efficiency and land productivity. In accordance with the previous discussion, however, there is also another possibility, namely that that the difference in market prices was the result of psychological mechanisms and assessments about the future. By the early 1840s, there must have been a growing awareness that the open-field system was coming to an end, especially considering the absolute priority of enclosure and the successive breaking down of the system in village after village. If farmers began to regard enclosure as inevitable, it is conceivable that existing capital that was bound up in the old village structure (fences, buildings and so on) actually began to be regarded as worthless -a kind of "sunk capital" that no one was willing to pay for at the market. Hypothetically, therefore, it can be assumed that unenclosed land was traded at a lower price even in situations in which its underlying productivity was still comparable to that of enclosed land.

Thus, in order to identify which of these two scenarios best resembles the actual development, it is necessary to study the productivity of the two land regimes. 


\section{SEEDS, LAND RECLAMATIONS, AND CROPPING SYSTEMS}

The main source of the following analysis consists of probate inventories from deceased freeholders in the research area from 1795-1869 ${ }^{17}$. Of the 1,342 inventories used in the investigation, 1,081 provide information on seeds as part of farm capital. This fact enables us to measure grain cultivation within the two property regimes. In Figure 4, the seeds of grain, peas, and potatoes are measured in weighted barrels, using the methodology of Carl-Johan Gadd. Approximately one weighed barrel equals a net sown area of 0.5 hectare.

FIGURE 4

Seeds on enclosed and open-field land in the research area, 1809-68. Weighted barrels per $1 / 4$ mantal (arithmetic mean)
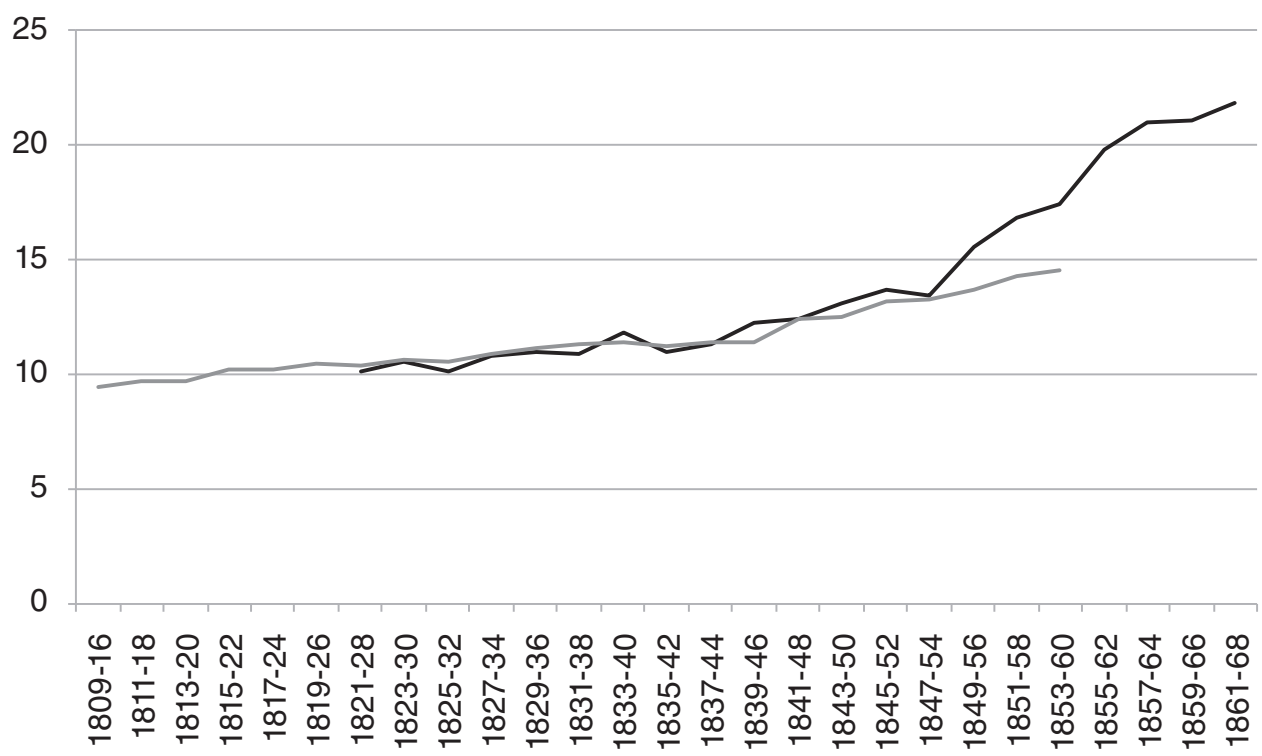

$$
\text { Enclosed land Open fields }
$$

Notes: 1 Swedish barrel of wheat $=1.33$ weighted barrel; rye, 1 ; barley, 1 ; mixed barley-oats, 0.67 ; oats, 0.5 ; peas, 1.33; potatoes, 0.33 (after Gadd, 1983: 90). 1 Swedish barrel = 156 litres. Observations from the year of the implementation of enclosures and the following three years have been excluded. The differences between the two categories of land during the period from 1849-60 are statistically significant at the 0.05 level if this period is not divided into shorter segments of time.

Sources: probate inventories from the häradsrätt local courts. (digital versions at www.arkivdigital.se; originals at Riksarkivet in Gothenburg); records of taxation and real estate (mantals och fastighetstaxeringslängder, Riksarkivet, Gothenburg); cadastral act registers; enclosure acts (www.lantmateriet.se).

17. See GADD (1980) on Swedish probate inventories as source material. 
FIGURE 5

Seeds from different crops on enclosed and open-field land in the research area, 1795-1869. Weighted barrels per $1 / 4$ mantal (arithmetic mean)

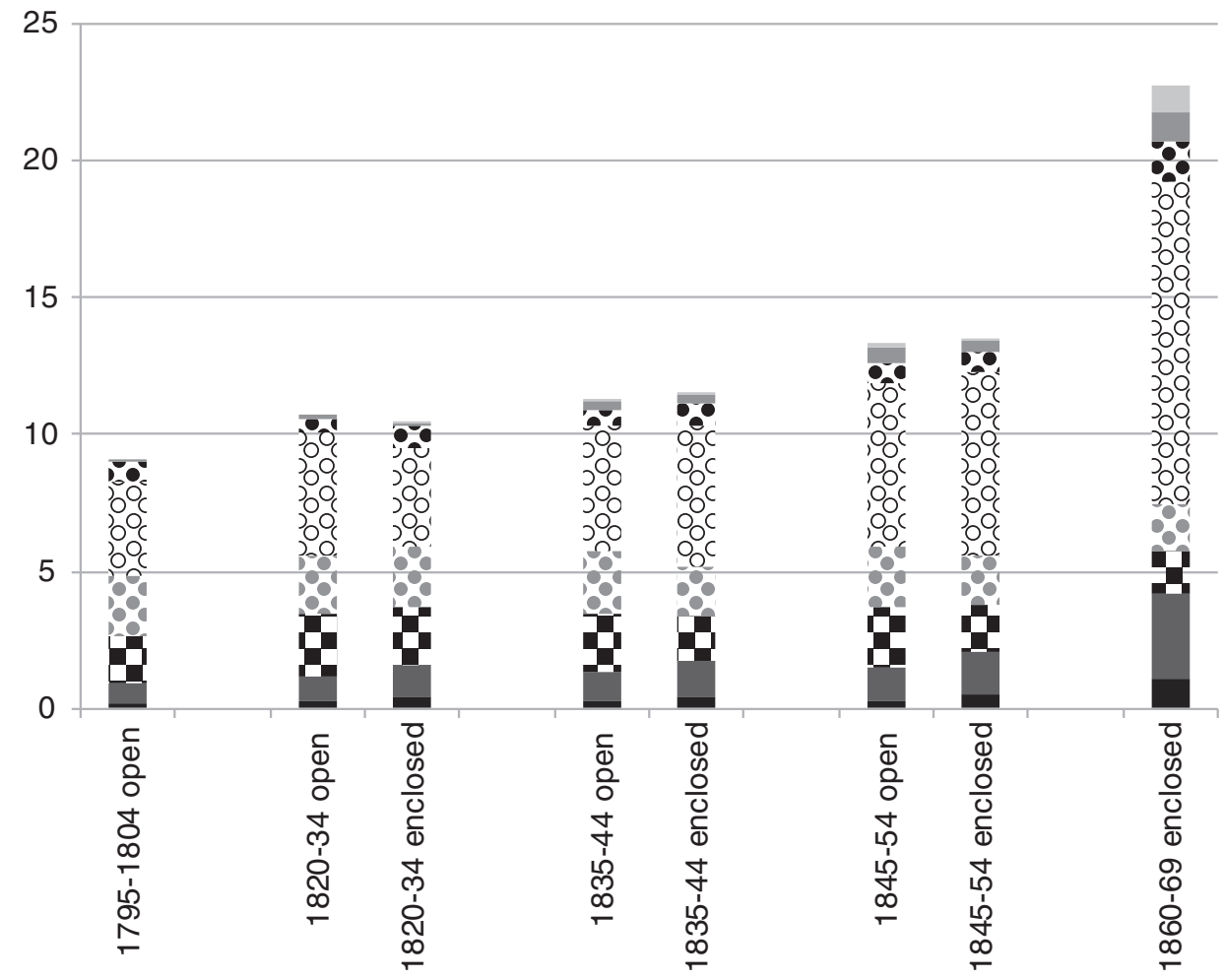

wheat $\square$ rye "barley mbarley-oats roats "peas $\square$ potatoes vetch Sources and notes: see Figure 4 . The differences between the two categories of land are statistically significant at the 0.05 level regarding wheat (all studied intervals) and rye (1820-34 and 1835-44).

According to Gadd's (1983: 223-24) interpretation, enclosures were one of the main driving forces behind land reclamations on the plains. Enclosures did not only incentivise farmers to convert more of their property into arable land. In fact, the reform actually forced them to do so, as the new land belonging to many farmsteads was comprised of meadows originally located on the outskirts of the old villages. This argument seems plausible and is commonplace in literature on the agrarian revolution in Sweden. It has, however, never been empirically tested. The results depicted in Figure 4 contradict this theory, as the amount of seeds remained almost identical over a long period of time in both property regimes. This observation implies that land reclamation was actually not greater on enclosed land. Not until the 1850s (when practically all land had already entered into the process of enclosure) can we observe a change in this respect. The amount of seeds 
on enclosed land then escalated, creating a gap between this land and the small remaining portions of open-field land.

In Figure 5, seeds from the individual crops are presented. These results enable a more detailed analysis of farming within the two systems.

Also with regards to crops, the seeds used on enclosed and open-field land long remained more or less the same. Presumably, this pattern would imply that crop-rotations were also similar.

According to contemporary agrarian reformers, one of the main advantages of enclosure was that it facilitated the transition to convertible husbandry ${ }^{18}$. In this way, fodder crops such as clover could be integrated into crop rotations, providing a solution to the old land-reclamation/fodder shortage dilemma.

Lamentably, there is no information about clover seeds in the probate inventories. The potential shift from a two-field system to convertible husbandry can, however, also be studied by looking at the cultivation of other crops. The old two-field system practiced on the plains was first and foremost a system of spring grain (barley, oats and mixed oats-barley) cultivation. Winter grain (wheat and rye) was difficult to cultivate since the best time for sowing was in August and would have interfered with common grazing on fallow fields. If temporary fences were not used, farmers would have had to wait to sow their rye until well into September, when the animals were moved from the fallow fields to the stubble on the harvested fields. This practice was risky since it shortened the growing season. As winter grains produced better yields than barley and oats and, as cash crops, were also more valuable, the difficulty in cultivating these crops was one of the main disadvantages of the old order. For similar reasons, potatoes and peas were also difficult to integrate into the twofield system and required temporary fences. If enclosed land farmers had abandoned the old system, we would expect a significant increase in the cultivation of these crops.

As can be seen in Figure 5, farmers on enclosed land did indeed cultivate more rye and wheat than farmers on open-field land. However, the difference was by no means conclusive and does not indicate a general shift towards convertible husbandry. It was not until the late 1850 s and 1860s that there was a distinctive change in this respect, with an increase in rye, wheat, potatoes and peas and the introduction of vetch as a fodder crop. In addition, the cultivation of oats grew as British market demand exploded, while barley and

18. This is stressed explicitly in the introductions of the ordinances of enskifte. 
mixed oats-barley fell behind. This shift occurred simultaneously with the massive increase in the amount of seeds discussed earlier. It does not require much imagination to identify this period as the time of the decisive breakthrough of convertible husbandry on the plain. This result is supported both by Carl-Johan Gadd's interpretation and contemporary reports from the area ${ }^{19}$.

Ultimately, enclosure seems to have had little immediate effect on cereal production on the plains. The major changes did not occur until towards the very end of the period of parallel existence, 45-50 years after the initiation of reform. Up until then, farming within the two regimes was very similar. Nevertheless, it is important to stress that the size of the yields is unknown. Was it greater on enclosed land? Due to the lack of contemporary data from the farm or village level, the question will be addressed indirectly, through an analysis of livestock possession.

\section{THE LIVESTOCK}

Livestock was, in several ways, the hub of the farming economy. Oxen and horses provided traction power that enabled the households to farm the land. The horse was used for transport and was also important as a status symbol. All animals provided the manure needed to maintain the fertility of the land. Given the situation described above (in which acreage under tillage remained almost identical for both enclosed and open-field land until the early 1850s) the possession of livestock is therefore an important indicator of the underlying productivity within the two systems. It reflects how much fodder the farms could produce. It indicates how much manure there was to fertilise the fields and, indirectly, probably also how large the yields were. In Figure 6, the number of horses, oxen, and cows within the two systems is presented.

Similar to the case of the seeds, there is an increase in livestock on enclosed land towards the end of the period. Until the early 1850s, however, enclosed-land farmers were not better equipped with livestock than farmers with open-field land.

A closer look reveals some differences between the two systems. Farmers with enclosed land tended to own slightly more horses than farmers with open fields. The latter, in their

19. GADD (1983: 229-31, 249, 274). The shift can be followed in the 5-year reports from the Enforcement officers (Kronofogdarna i Läckö och Skara fögderier; handlingar till femårsberättelser; GLA) and in parish reports to the Swedish financial committee of 1858 (Finanskommittén 1858; inkomna handlingar, $R A$ ). 
turn, possessed more oxen. Horses were, in several ways, the "up-market" alternative; they worked faster, demanded more fodder, were more expensive, and offered more prestige to the owner. Oxen provided more traction power per unit of fodder but were slow and of insignificant symbolic value. Consequently, the fact that enclosed-land farmers owned more horses would suggest a slight advantage for this property regime in terms of economic performance. It must, however, be noted that the only differences that are statistically significant at the 0.05 level are those regarding oxen.

\section{FIGURE 6}

Possession of horses, oxen and cows on enclosed and open-field land in the research area, 1795-1869. Number of animals per $1 / 4$ mantal (arithmetic mean)

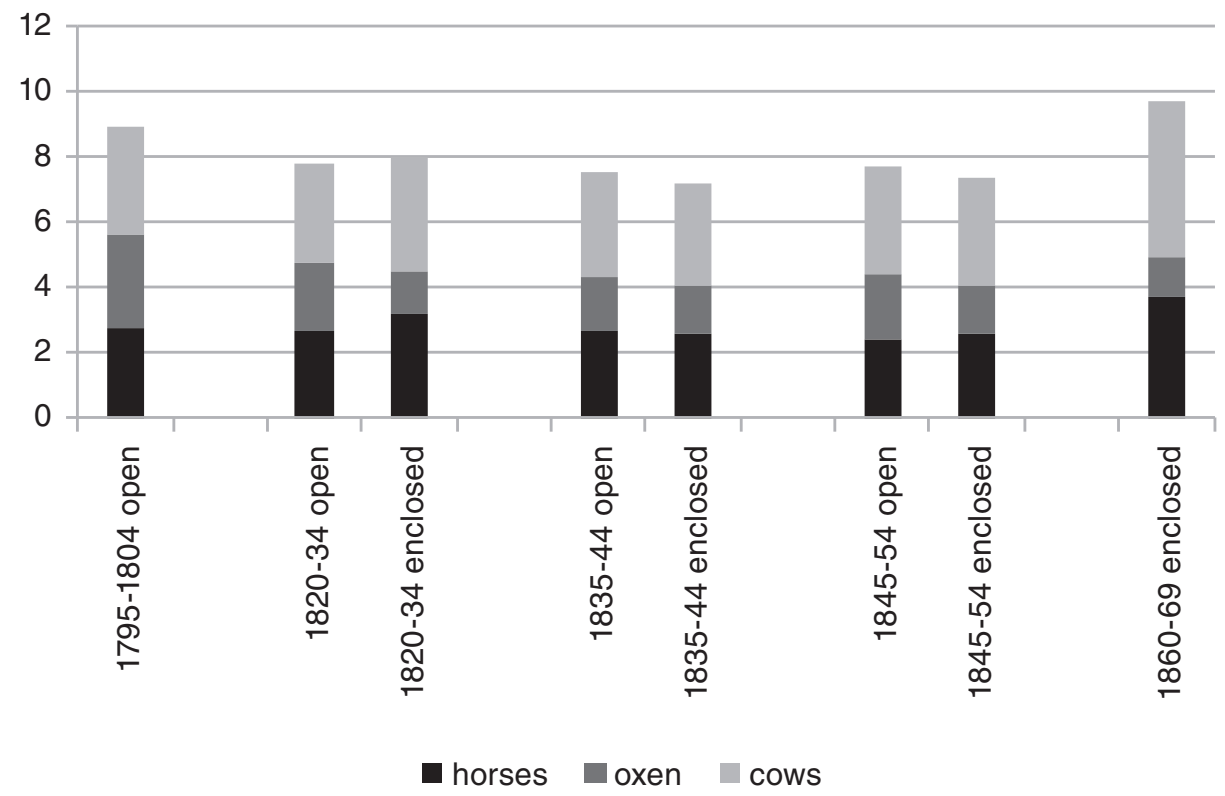

Notes: 1 bullock is counted as 0.5 oxen. The differences in possession of oxen 1820-34 and 1845-54 are statistically significant at the 0.05 level.

Sources: see Figure 4.

Thus far, the numbers of animals have been discussed. What has not yet been taken into account is the quality of the livestock. Better-fed animals weighed more, were stronger, and produced more manure. They were also traded at higher prices on the market. Figure 7 compares the values of horses and cows (the two animals found on every farm) in probate inventories from the two categories of land. In Figure 8, the total value of all animals on the two types of farms is presented. 


\section{FIGURE 7}

Average value of horses (above) and cows (below) in the research area, 1820-61. Riksdaler riksgäld per animal (arithmetic mean)

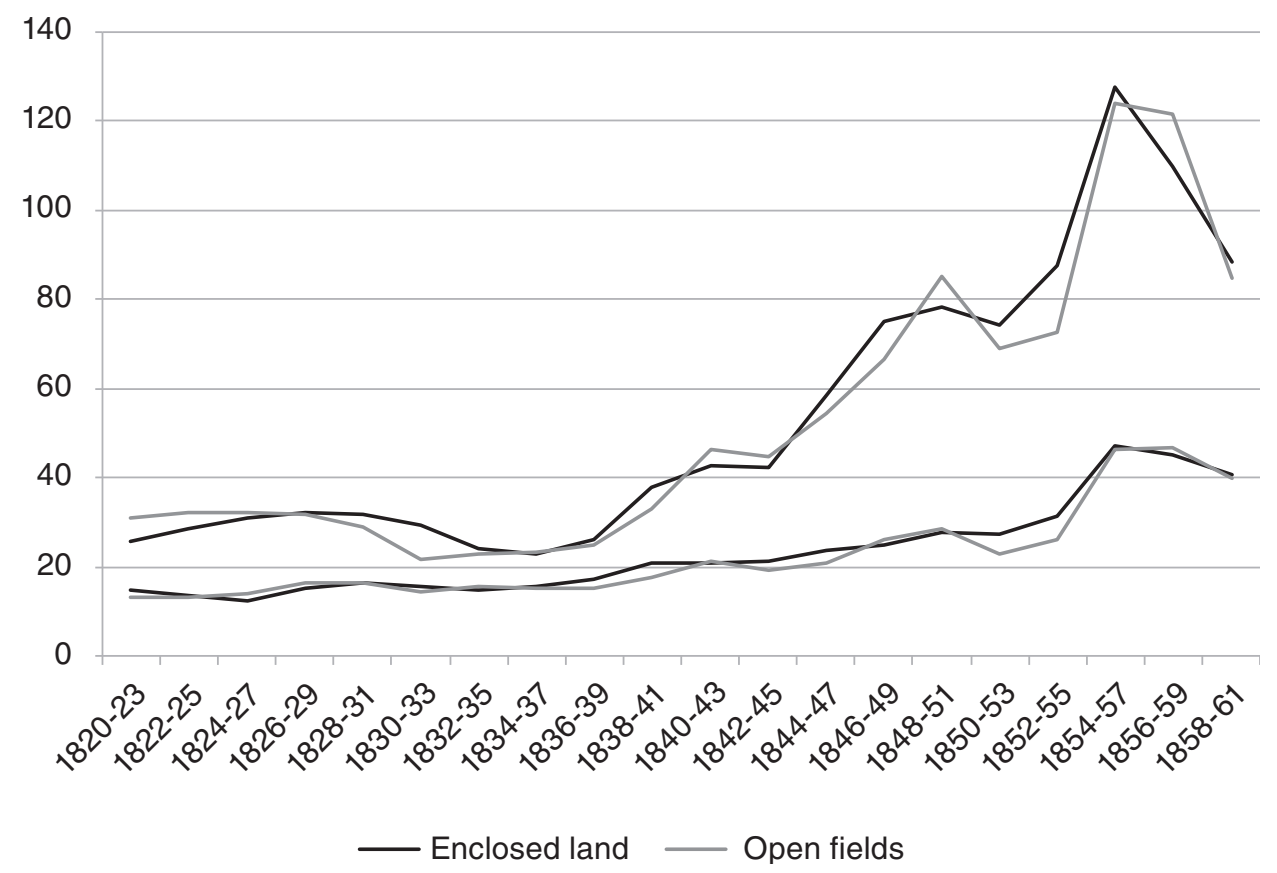

Sources: see Figure 4.

The most important tendency shown in the figure is that animal values for both categories of land rose sharply from the late 1830s and onwards. Inflation explains part of this development; the consumer price index rose 30\% in 1840-60 (Edvinsson \& Söderberg, 2011). The rising values of the livestock must, however also reflect an increase in their size and quality, which reasonably also suggests that they were better fed. As this development started before convertible husbandry and clover cultivation had begun in earnest, the most probable source of new fuel for the animals was an increased use of oats as fodder. This improvement in feed could be achieved just as easily in an open-field system as on enclosed land.

Not until the very last years of the investigation, when there were only small portions of open-field land left on the plains, can we distinguish a difference between the two regimes. In this period, enclosed land seems to gain an advantage in terms of the total value of the livestock. Even if the difference is not statistically significant, it certainly makes sense in the light of the previous result of the study. The fact that farmers with enclosed land adopted convertible husbandry from the 1850s must have improved the fodder situation 
within this system. At the same time, more draught animals were required on enclosed land as grain cultivation rapidly expanded.

FIGURE 8

Total value of the livestock on enclosed and open-field land in the research area, 1820-61. Riksdaler riksgäld per 0.25 mantal (arithmetic mean)

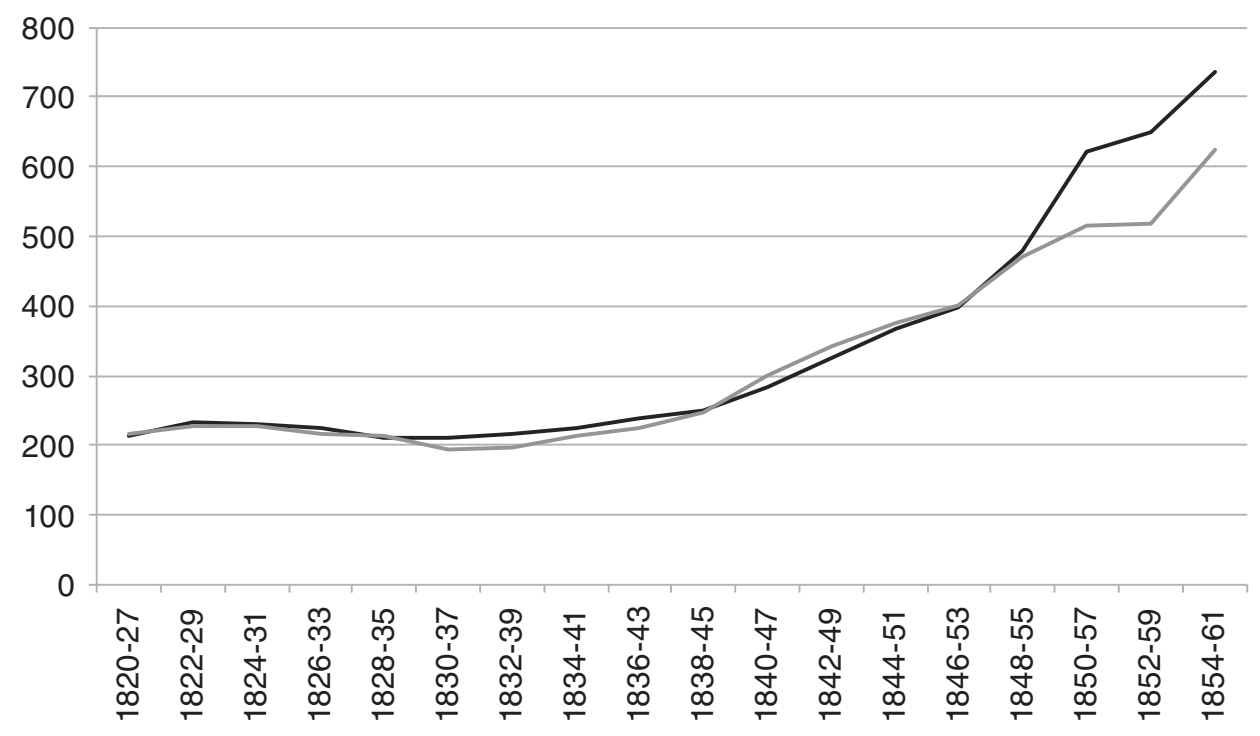

\section{— Enclosed land —open fields}

Note: the differences after $c a .1850$ are not statistically significant at the 0.05 level.

Sources: see Figure 4.

\section{THE SPREAD OF INNOVATION: THE IRON PLOUGH}

The final section of the empirical study involves an analysis of the introduction of the iron plough. According Carl-Johan Gadd (1983: 153-60, 259-62) this adoption was one of the most important agricultural innovations on the plains, reducing the animal power needed to work the land. Figure 9 presents the breakthrough of the innovation. In order to be able to follow the process from the beginning, the plough's early development on enclosed land has been included in the figure, even if it is based on a very limited number of observations.

The scarce empirical evidence from enclosed land from the 1810s indicates that the introduction of the iron plough began earlier on this category of land. This phenomenon was probably due to the fact that several early enclosed villages were situated very close to what, from Gadd's $(1983: 157,159)$ results, can be identified as the epicentre of the 
spread of the new invention: the peninsula of Kålland, a few miles northwest of the research area. All early enclosed-land ploughs are from villages close to this area.

\section{FIGURE 9}

The spread of the iron plough on enclosed and open-field land in the research area, 1811-43. Percentage of farms with the best plough in iron

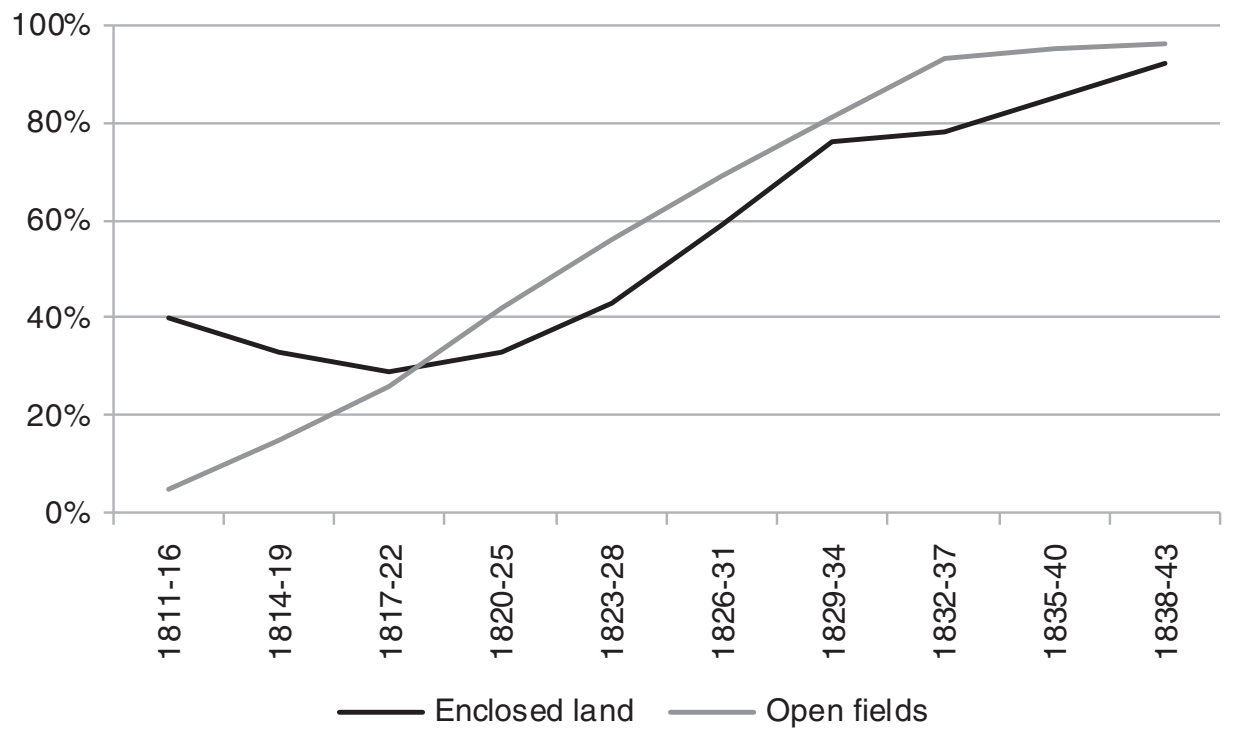

Notes: if the designation is unclear, the type of plough has been determined from the value of the plough (iron ploughs were considerably more expensive than other ploughs) according to Gadd's (1983: 153-56) methodology. The differences between enclosed and open-field land after $c a .1820$ are not statistically significant at the 0.05 level. The earliest cohort for enclosed land is based on only 5 observations.

Sources: see Figure 4.

Once iron ploughs had started to take off, their use appears to have advanced somewhat faster on open-field land. The fact that farmers lived close together in villages and could study the use of the new plough when neighbours worked the land on the adjacent strips might have accelerated the spread of innovation within the open-field regime. It must nonetheless be stressed that the differences between the two categories of land are small and by no means statistically significant.

\section{THE RE-EMERGENCE OF THE OLD ORDER WITHIN THE NEW REGIME}

Thus far, it can be concluded that, over a long period of time, there were striking similarities between the two property systems. In spite of the massive reorganisation of the agri- 
cultural and institutional landscape, farmers with enclosed land did not reclaim more land, sow more seeds, or possess more animals than farmers with open-field land. Neither did they adopt innovations such as the iron plough more rapidly. Most strategic in this context is the fact that farmers with enclosed land also continued to employ the traditional two-field system up until the 1850s, when convertible husbandry was finally adopted. It was not until then, in the very last phase of the "parallel existence", that the system of enclosed land secured a clear advantage over the open-fields. Why did the dynamic effects of the reform not come earlier? Why did the farmers with enclosed land not adopt convertible husbandry right from the start?

According to observers of the time, there were several problems attached to the adoption of modern cropping systems on the plains. In the old order, half the fields were put aside as fallow every year. This system might seem like a big waste of land, but was a result of the fact that the fallow was necessary for working and preparing the stiff and heavy clay soils, both mechanically and with the help of the winter frost. Within convertible husbandry, fallow land was drastically reduced. Most of the ploughing now had to be performed during the busy spring season, which could create insurmountable demands on both draught animals and human labour. In addition, convertible husbandry required heavy complementary investments if its potential was to be exploited properly -not least the draining of the wet, clayey soils ${ }^{20}$.

Another problem connected to the change in farming system concerns the issue of fences. As has been stated above, farmers in the area did not have their own wood resources; everything had to be imported. The central foundations of the old agricultural regime (the two-field system, the large villages, and the enormous grazing communities that covered the open fields of several villages) were all aimed at reducing these costs as much as possible. The fundamental idea behind enclosure provided the opposite approach: each farm should be fenced separately. In practice, this would indicate that the total length of the fences was multiplied. If convertible husbandry was to be adopted in addition to enclosure, the length of the fences would have to be multiplied once more. The two-field system had, as is apparent by its name, two fields; convertible husbandry with crop rotation in this region typically had eight.

For contemporary farmers, the use of eight separately fenced fields was simply not an option. Thus, they continued to use the old two-field system in the enclosed regime ${ }^{21}$. Fur-

20. Skaraborgs Läns hushållnings sällskaps tidning (1852: 3); ARRHENIUS (1848: 181-92); GADD (1983: 213-18).

21. In addition to the evidence from probate inventories, land use on enclosed land can be studied 
thermore, as landowners farmed their land in a similar manner side-by-side, it was in fact also possible to integrate fences between neighbours and leave the fields open to allow grazing over the boundaries between the farms. These kinds of systems can be discerned on a number of cadastral maps of farms from the area ${ }^{22}$. Thus, not only the two-field system was re-established in the enclosed regime, but also, to some extent, the open fields!

One important factor in this context is that many enskifte and early laga skifte enclosures in this region were actually implemented in a way that facilitated this sort of cooperation over fences. Even if the pronounced idea behind the reform was that each farm unit should be separated from its neighbours; in practice larger units of partition were commonly used. Thus, if the landowners within the same "land register unit" (jordeboksenhet) agreed, up until about 1840 , they were, in general, permitted to secure their share of the village in one common allotment ${ }^{23}$. Typically this type of unit consisted of $0.5-1$ mantal and harboured two to five individual farmsteads. If these farms were treated as one unit during enclosures, the costs of the reform could be kept down, an ambition that is sometimes explicitly expressed in the enclosure proceedings ${ }^{24}$. The concerned parties were then left to decide how to divide up their new land within each land-register unit. From later records of land surveillance, we know that they often chose to develop types of hamlets with a system of shared fences ${ }^{25}$.

The fact that the practise of common grazing also re-emerged in the enclosed regime seems to destabilize the initial hypothesis of this study. The principal purpose was to investigate the co-existence of two parallel agricultural systems on the plains. However, based on the sources, it can be shown that there was in fact a much more complex mosaic of

on the cadastral maps made for the subdivision of farms, hemmansklyoning. Some examples of a restored two field systems are: Rävegården, Uvered 1857 (16-UVE-33); Skumpagården, Jung 1851 (16-JUN-22); Bengt Olofsgård, Hasslösa 1842 (16-HHA-18); Christiansgård, Toketorp, Järpås 1844 (16-JÄJ-38); Kungsgården, Badene, Kvänum 1856 (16-KVJ-24).

22. For example: Stora Brätteberg, Jung 1847 (16-JUN-19); Christiansgård, Toketorp, Järpås 1844 (16-JÄJ-38); Svenningsgård, Synneråhl, Saleby 1861 (16-SBY-66); Storebacken, Rycka, Trässberg 1847 (16-TRG-21).

23. In 20 out of 20 enskifte enclosures and 9 out of 13 laga skifte enclosures initiated before 1840 (not including partial enclosures and villages without land register units with several owners) at least part of the village was enclosed with the land register unit as unit of partition.

24. See for example laga skifte in Resville, Norra Härene, 1835-36. The land surveyor advocated an enclosure based on the individual land holdings. Most free holders disagreed, claiming that the costs of such a partition would mostly drive us into ruin. Their request to get their land in one common allotment for each land register unit was respected (48, p. 12; Litt E, p. 21).

25. For example: Tåstorp, Synnerby 1850 (16-SYN-41); Skumpagården, Jung 1851 (16-JUN-22); Stora Brätteberg, Jung 1847 (16-JUN-19); Böljan, Hasslösa 1850 (16-HHA-29); Bengt Jonsgården, Hasslösa 1850 (16-HHA-31); St Västhed, Rycka, Trässberg 1854 (16-TRG-36). 
competing farming systems, including informal grazing communities and new hamlets on enclosed land. It is important to consider whether or not these "imperfections" in the reform also caused the problems for enclosure on the plains. If land surveyors had been more consistent, maybe the reform would have been more of a success. The material has been crosschecked; individually enclosed farms were compared to enclosed farms within land-register units. The differences in economic performance between these two subcategories of enclosed land were however small and not to the advantage of the individually enclosed farms ${ }^{26}$.

From this perspective, there is reason to consider another point of view. The fact that farmers chose to re-establish part of the old regime within the new strongly suggests that they considered this to be the best way of conducting farming on the plains. The inconsistencies in the implementation of the reform were thus a rational response to its shortcomings.

However, over time, the forces incentivising a more fundamental agrarian change were gradually strengthened. The population grew continuously, and most of this increase occurred within society's landless segments (Gadd, 1983: 76-87). This development facilitated work-intensive investments such as ditching. At the same time, better transport and credit institutions made markets and capital more accessible.

Ultimately, it was the economic boom of the 1850-70s, fed by the Crimean War and the subsequent export of oats to England that provided the stimulus for a major change in farming techniques in the region. This shift included the introduction of convertible husbandry, as well as heavy investments in ditching. Once the land was drained, a new and more efficient type of iron plough was also adopted. Together, these improvements enabled local farmers to master the heavy clay soils without fallow. Finally, the problem of fencing was solved by tethering or shepherding the animals ${ }^{27}$. The use of fences was almost completely given up, an ingenious but also rather inconvenient solution ${ }^{28}$.

In this way a new farming regime was finally established, based on the pillars of enclosure, convertible husbandry, ditches and fenceless farming. The point is, however, that

26. Seeds 1834-54 were similar; farms enclosed at farm register unit level (excluding units later subdivided by acts of hemmansklyvning) hade somewhat more animals than individually enclosed farms; up till ca. 1845 they were also traded at higher prices, later this was reversed.

27. The inner logic of the new farming regime is discussed in GADD (1983: 226-27, 232-36, 25153).

28. According to the cadastral hemmsklyoning maps fences disappear gradually during 1845-65, first the internal fences at the farms and later the fences between farms. 
this defining moment did not come until the process of enclosure was already almost completed. For the first 45-50 years of the agricultural systems' parallel existence, this new farming regime was still not available as a realistic alternative to the freeholders on the plains.

\section{THE POLITICAL ECONOMY OF ENCLOSURES AND OPEN FIELDS}

In the following, the theoretical aspects of the investigation and the underlying logic of the systems' parallel existence will be considered and discussed. This will be done by contrasting the findings regarding land productivity, such as seeds (Figure 4) and animal values (Figure 8), with the findings regarding market value for land (Figure 3) within the two property regimes. Three distinctive periods can be discerned:

a) The period up until the early 1830 s, when enclosed land was traded at equal or lower prices than open-field land and showed indicators of land productivity at like levels.

b) The period from the early 1830 s until the early 1850 s, when enclosed land was traded at substantially higher prices while production remained similar.

c) The period from the early 1850 s, when enclosed land had also gained an advantage in terms of production.

In the first period, freeholders had few reasons to opt for an enclosure. Agricultural production was not greater on enclosed land, which in practice meant that the resources spent on the reform offered no returns. Neither did the agricultural land market offset the costs of the reform. Enclosure was in both these respects a sunk investment.

It must have been clear to freeholders from early on that enclosure was a risky business. Accordingly, up until the mid-1830s, most enclosures were initiated by noble landlords, merchants from the cities, or state officials who held crown land as part of their salary $^{29}$. In many cases, these enclosures were probably formed with the intention of creating modern, large-scale agrarian enterprises in the English fashion. Given the fact that the relative costs for fencing decreased with the increased size of the holding, and also con-

29. Out of the 33 enclosures initiated before 1835, 20 were initiated by noble landowners, gentlemen farmers, state officials, or city merchants, and 10 by free holders. In 3 cases, the initiator cannot be identified in the proceedings of enclosure. 
sidering the potential re-distributional effects if former peasant tenants were replaced by landless wage labourers as a part of the reform, such projects might also have enjoyed reasonable prospects of success. As long as it was legally possible (prior to 1827), these initiatives sometimes resulted in partial enclosures in which the applicant's land was removed from the common fields, but usually whole villages were dragged into the process, on some occasions against the expressed will of the peasant landowners. From the example of the transition in neighbouring villages that have ended up in a highly precarious situation considering the costly maintenance of the fences, we foresee our ruin, claimed the 40 freeholders in the village of Jung in 1825 to the land surveyor, who had been appointed by the absent noble landlord who owned one-fifth of the village ${ }^{30}$. Evidently, some freeholders also initiated enclosure; according to the law, each and every one of them had the right to do so. However, only a dozen of the approximately 3-4,000 freeholders in the area studied did so in the first 30 years of enclosure legislation ${ }^{31}$.

By the mid-1830s, the economics of enclosure had changed with regards to one central aspect: a higher land value now compensated for the cost of the reform. On the other hand, enclosed land was still not more productive than open-field land in terms of grain or livestock, which in fact makes it somewhat difficult to explain why this category of land was now more expensive. There is no reason to believe that, for example, labour productivity within the two regimes had changed dramatically by this time. Instead, another factor had changed, namely the expectations regarding the future. The fact that open-field land was now traded at lower prices -despite it being just as productive as enclosed landsupports the assessment that a situation had arisen in which the enclosure of the remaining open-field villages was regarded as being inevitable in the long run -or at least so likely that nobody was willing to pay for open-field bound capital. This type of capital had thus become sunk capital.

Another way to express this supposition is that that open-field land was cheaper since its buyers would have also had to bear the costs of a forthcoming enclosure. From this perspective, the price difference between enclosed and open-field land after 1840 should, in fact, equal the market's evaluation of the costs of the reform.

30. Proceedings of enskifte enclosure in Jung 1825, first meeting, page 5, archives of Lantmäterimyndigheten (www.lantmateriet.se). The fact that the villagers, according to the enskifte legislation, had the legal right to stay out of the reform is not reflected in the proceedings. The enclosure was appealed -only to be implemented as a laga skifte after 1827 .

31. Out of the 10 enclosures initiated by freeholders before 1835 , there was one single applicant in 7 cases. In the remaining cases the numbers of applicants cannot be established from the proceedings. 
Under these conditions, enclosure remained an uncertain project. Even if the cost of the investment was now offset by the land market, it did still not yield any higher output from the land. It was in this respect still a sunk investment. Consequently, it was still rational for landowners not to enclose.

Nevertheless, at this point, the period of the systems' parallel existence now approached its end. From 1838 onwards, new villages entered the process of dissolving the open fields every year. In contrast to the early phase, most enclosures were now initiated by freeholders. What did these farmers expect to win from enclosure if land productivity was not higher than in the old regime? If open fields were still the most rational option, why did they not endure?

In order to answer these questions, it is necessary to distinguish between the aggregate and individual level, and between long and short-term perspectives. Even if enclosures were not rational in general, they might have in fact been regarded as rational by individual landowners. With access to capital and with a bit of strategic behaviour or luck in the partition of the land, enclosure might indeed have been fruitful in individual cases. In addition, it was this individual level that counted since according to the absolute priority of enclosure, every landowner had the right to initiate the process. Some of these applicants might also have been forerunners in the shift to new farming technology, experimenting with convertible husbandry before it was generally considered viable.

Central in this context were prospects for the future. Evidently, the old order was gradually breaking down. When neighbouring villages were enclosed, common grazing of livestock over village boundaries was no longer possible. In these cases, villagers in the openfield villages had to share the costs of building and maintaining the fences that were erected on previously open borders. In addition, the two-field system was getting increasingly clumsy. By the $18^{\text {th }}$ century, peas were being cultivated within temporary fences on fallow land. Towards the middle of the $19^{\text {th }}$ century, winter rye, potatoes, and probably, on some farms, clover were sown in a similar manner. The system still prevailed -but would it support future developments? Furthermore, the time horizon of investments was crucial to the farmers' evaluation of the situation; they might have wanted to erect new buildings or drain the wet clay soils. All such investments ran, from the perspective of a possible future enclosure, the risk of becoming sunk investments. In order to have a secure investment time horizon, the foresighted and forward-looking farmer needed to enclose.

In addition, also the fact that the real estate value of open-field land had been downgraded must have put pressure on the old regime. This fact could be ignored on farms where there was a future prospect of continuity in farming within the household. In the 
case of a freeholder who planned to sell his land however, the situation was different. In practice, he then had to bear the costs of enclosure, as his land was now worth less -even if he and his fellow villagers had chosen to stay out of the enclosure process. From this perspective, the alternative cost of actually implementing an enclosure was zero.

In several ways, the prospects of future enclosures were thus also the driving force behind the actual implementations of enclosures. As demonstrated earlier, these prospects were not yet based on the enclosed regime's supposed economic superiority. They were based on institutional arrangements, most notably the absolute priority of enclosure, which, in the long run, made the reform almost inevitable.

For the village as an institution, the absolute priority of enclosure meant that it faced a situation in which the veto of a fellow villager could end its existence. Every quarrel over, for example, demarcation lines between strips of land, every dissatisfaction with common decisions to do with grazing or fences, every antagonism or misunderstanding at the personal level threatened to escalate, which could destroy the whole village. Anyone who owned a piece of land in the village could use the threat of enclosure to blackmail or demand special privileges, such as the right to temporarily enclose parts of the open fields. The power of the collective could in every instance be trumped by the will of the individual. Unanimity was required if the village was to endure.

From this perspective we could just as well pose the question the other way around: How did such institutions survive for so long? Considering the size of many villages on the plains, the situation must have been highly unwieldy and unpredictable. In both Öttum and Storvånga, there were 80 individual landowners. Land was bought and sold, new stakeholders entered the communities, people grew old or died, and new personal relations and government structures had to be established. Yet, in these two villages, it took until 1849 and 1850, respectively, until a general enclosure was finally initiated. It must have taken the force of a very strong common incentive which bound the villagers together for the village institution to survive for so long. This common incentive was not based on a cultural preference for village life and traditional farming. It was based on the basic fact that enclosure did not yet offset its cost for the vast majority of villagers. New villagers entering the community bought their land at a reduced price; they had made a good deal -until that very moment when a fellow villager applied for enclosure.

There are a few, interesting examples of how villagers handled this risk. In 1844, the 45 villagers of Längjum set up a mutual contract. It stated that the individual who applied for enclosure would bear the full cost of the reform, including for the rest of the vil- 
lagers ${ }^{32}$. In other cases, there are examples of peer pressure that, if the common will of the community was still being ignored, could evolve into threats or even violence. In Edsvära, the fruit trees and carriages of the applicant were supposedly destroyed as a warning $^{33}$. In Fyrunga, things got even further out of control. The person who applied for enclosure was the object of intimidation, derision, and eager persuasion in an attempt to force him to withdraw his application. In the end, an angry mob of fellow villagers chased him down to the river where he, in a failed attempt to get safely over to the other side, drowned. Local tradition in Öttum tells a different story; the applicant (an outsider) is supposed to have used the threat of enclosure as a form of speculation and was bought out with a considerable amount of money. In this way, open fields survived for another few years. The situation can be compared to the English case in which bribes and intimidation were used in order to convince reluctant stakeholders to participate in the reform so that the required unanimity (in the pre-parliamentary situation) or qualified majority (parliamentary situation) could be achieved. On the plains of western Sweden, it was the other way around; bribes and intimidation were used to make eager stakeholders refrain from exercising their right to enclose, so that the open fields would continue to exist.

In conclusion, it can be seen how the villagers were trapped by the contradictions of the systems' parallel existence. Villagers were trapped between the old, open-field bound capital as sunk capital and enclosure as a sunk investment; between the common endeavour to avoid enclosure and the individual right to veto this endeavour; and between a stubborn defence of the old order and a growing awareness that this order would not prevail.

It was not until the 1850 s and the adoption of a new farming regime based on convertible husbandry, ditching, and tethering that this contradictory situation came to an end. In light of the new prospects that were rapidly opening up, previously reluctant freeholders could now embrace enclosures as one of the pillars of their growing prosperity. It should likewise be noted that the pioneers of the reform were not its winners. The true victors of this transition were actually the farmers who managed to avoid enclosures up until the 1850s and who could make a direct leap from open-field farming to tethering and convertible husbandry on enclosed land. In this way, the period in which enclosures did not offer any financial gain was avoided, as were the heavy investments in fences, which had long been associated with the reform. With the advancement of the new fenceless farming regime, such enclosure-bound capital now increasingly became sunk capital.

32. Proceedings of the cancelled laga skifte enclosure in Längjum and Östby 1850, first meeting, 3, archive of Lantmäterimyndigheten (www.lantmateriet.se)

33. This and the following examples are discussed in Nyström (2007) and HofFMAN (1989). 


\section{CONCLUSIONS}

One of the contradictions of enclosures is how they both promoted and threatened property rights. The aim of the reforms was to establish modern, uncontested land-ownership. In order to realise this ambition, however, existing property rights had to be demolished.

Legislators in Europe tackled this dilemma in different ways. At one extreme is the situation in pre-parliamentary England or in $19^{\text {th }}$ century France, where unanimity among landowners was required for a reform. During English parliamentary enclosures and in several $19^{\text {th }}$ century German states, a qualified majority was considered enough ${ }^{34}$. At the other extreme is the Swedish laga skifte legislation, where it only took a petition from one stakeholder to enclose a village.

In this study, the parallel existence of enclosed and open-field land systems on the plains ofVästergötland provides the starting point for a discussion on the economic and institutional mechanisms of Swedish enclosures. The first villages in this area were enclosed in 1805, and the last ones in the 1860s. The fact that the two systems coexisted during half a century enables us to examine source materials such as probate inventories and registers of land sales in order to reconstruct the farming practices, production, and land values that existed within the two regimes, using the area as an "historical laboratory" of enclosures and open fields. At the same time, the period of parallel existence has also been a discrete object of inquiry. Given the fact that villages in the area were big (up to 80 farmsteads), how could open fields have survived for so long in a situation where every landowner could veto their existence?

This investigation has shown that the main explanation for the slow acceptance of reform was that it offered few advantages for farmers on the plains. Productivity was not higher on enclosed land than on the open fields, and there were no dynamic technological effects coupled with the reform. Commonly, the traditional two-field system was reestablished after enclosure, sometimes even including elements of common grazing. These practices indicate that the old regime was still widely considered to be the best way of conducting farming on the plains. From this perspective, it was above all strong institutional imperatives that drove the reform process forward.

Evidence from the land market offers a complementary outlook on these developments. During the initial phase of the studied period, enclosed land was traded at lower prices than open field land. Given the costs of the reform, this was a discouraging pattern. From the

34. On France and Germany, see Grantham (1980) and Hoffman (1989). 
1830s, however, the situation was reversed; now, the land value of open fields lagged behind. As land productivity within the two regimes was at similar levels, the most probable explanation for this divergence is that buyers were no longer willing to pay for old openfield bounded capital, given the high probability of enclosure. It was not until the $1850 \mathrm{~s}$ that major shifts in farming technology finally took place within the enclosed regime, including a shift from the two-field system to convertible husbandry and a rapid increase in cereal production. This was almost a half century since the first enclosures on the plains.

While recent Swedish research largely portrays the country's course of enclosures as a great success, the more complex understanding of the process outlined in this article agrees to some extent with studies of other countries, which contest the alleged superiority of the enclosed regime ${ }^{35}$. It must nonetheless be noted that, although the effects of enclosures in the study area long remained limited, the reform was still a necessary precondition for the post-1850 agrarian take-off.

One critical question that this article has not been able to fully answer is why this turning point did not come earlier. One problem was that high costs for fences combined with the hard-worked clay soils hampered the introduction of convertible husbandry. Reasonably, the agrarian take-off depended on a whole set of interconnected factors, including aspects of technology as well as access to labour, markets, and capital. Enclosure was part of that picture -but it could not alone initiate a change.

The transition to a modern farming regime was not as complicated everywhere in Sweden. The cradle and the showroom of Swedish enclosures was the southernmost province of Scania. Starting on the Söderslätt plains, both enclosures and convertible husbandry rapidly spread over the province during the first decades of the $19^{\text {th }}$ century. Why was the reform so successful in this area and not on the Västergötland plains? Hopefully, future research can provide an answer. The fact that the best-yielding agrarian districts in the country are in the south must however have been one strategic factor; the Söderslätt plains, where the reform first took off, possess some of the most fertile soils in Europe. With higher yields, surplus production was larger, which in its turn stimulated market integration all these factors must have been crucial in pushing the region towards enclosure. In addition, soils in the south are comparably light, which facilitated the introduction of convertible husbandry ${ }^{36}$.

35. See, for example Allen (1982, 1992), Clark (1998), Beltrán (2016), Moor (2009) and OsTROM (1990).

36. HELMFRID (1961), chronology of enclosures; OlSSON and SvENSSON (2010), effects of enclosures in Scania; GADD (1998: 178-95), introduction of convertible husbandry; HANSSON (1992:31), 
Once the reform expanded beyond this core area, it had declining success. On the vast and heavy clay plains in Östergötland and the MalarValley enclosures and convertible husbandry did not gain momentum until the 1850-80s, and the same is true for most woodland areas in the country ${ }^{37}$. In these regions, villages were smaller than on the Västergötland plains, which probably made it easier for the villagers to manage the uncertainties of enclosure. Still, the basic political economy of enclosure must have closely resembled the one described in this study, with strong institutions promoting a reform that most farmers did not yet consider economically viable.

In terms of a broader European context, the contrasts with the classical English case of enclosures should finally be considered. While in England, unanimity (in the pre-parliamentary situation) or a qualified majority (during parliamentary enclosures) was required to enclose land, in Sweden during laga skifte, unanimity was in fact required to avoid enclosure. And while the institutional situation in England probably delayed enclosures that were rational from the large-scale landowners' perspective, the reversed Swedish institutional situation seems to have hastened enclosures in a situation when open fields were still more rational from the free holders' point of view.

\section{ACKNOWLEDGMENTS}

We would like to thank Klas Dahlén and Linus Karlsson for archival support, Sara Ellis Nilsson and Rachel Pierce for language editing, Ole Aslaksen for GIS assistance, and the three anonymous reviewers of Historia Agraria for helpful comments on the manuscript. Earlier versions of the work were presented at the Permanent European Conference on the Study of Rural Landscapes in Gothenburg in 2014 and at Rural History in Girona in 2015. We are thankful for the comments put forward during these conferences. Ekmansstiftelserna and Västergötlands Fornminnesförening supported this research.

\section{REFERENCES}

ÅBerg, A. (1953). När byarna sprängdes. Stockholm: LT.

ALLEN, R. C. (1982). The Efficiency and Distributional Consequences of Eighteenth Century Enclosures. The Economic fournal, 92 (368), 937-53.

fertility; SöDERSTRÖM and PIIKKI (2016: 7, 12), soil textures.

37. See footnote no. 36. 
Allen, R. C. (1992). Enclosure and the Yeoman:The Agricultural Development of the South Midlands, 1450-1850. Oxford: Oxford University Press.

ARRHENIUs, J. P. (1848). Berättelse öfver förhandlingarne vid det andra Allmänna svenska landtbruksmötet $i$ Stockholm 1847. Stockholm.

Beltrán, F. J. (2016). Common Lands and Economic Development in Spain. Revista de Historia Económica-fournal of Iberian and Latin American Economic History, 34 (1), 111-33.

Carter, P. (1998). Enclosure Resistance in Middlesex, 1656-1889: A Study of Common Right Assertion. PhD thesis. London: Middlesex University.

Chapman, J. \& SEeliger, S. (2001). Enclosure, Environment E Landscape in Southern England. Stroud:Tempus.

Clark, G. (1998). Commons Sense: Common Property Rights, Efficiency, and Institutional Change. The Fournal of Economic History, 58 (1), 73-102.

Dahlman, C. J. (1980). The Open Field System and beyond: A Property Rights Analysis of an Economic Institution. Cambridge: Cambridge University Press.

Dyer, C.C., Thoen, E. \& Williamson, T. (Eds.) (2018). Peasants and their Fields: The Rationale of Open-Field Agriculture, c. 700-1800. Turnhout: Brepols.

EDVINSSON, R. \& SöDERBERg, J. (2011). A Consumer Price Index for Sweden 1290-2008. Review of Income and Wealth, 57 (2), 270-92. (Price index available at http://www.historia.se/Jamforelsepris.htm).

GADD, C. J. (1980). Swedish Probate Inventories, 1750-1860. In A. vAN DER WOUdE \& A. Schuurman (Eds.), Probate Inventories: A New Source for the Historical Study of Wealth, Material Culture and Agricultural Development. Wageningen: Afdeling Agrarische geschiedenis-Landbouwhogeschool.

GADD, C. J. (1983). Färn och potatis: Fordbruk, teknik och social omvandling $i$ Skaraborgs län 1750-1860. Göteborg: Göteborgs universitet.

GADD, C. J. (1998). Jordbruksteknisk förändring i Sverige under 1700- och 1800-talen: Regionala aspekter. In L. A. PALM, C. J. GADD \& L. Nyström (Eds.), Ett föränderligt agrarsamhälle:Västsverige i jämförande belysning. Göteborg: Göteborgs universitet.

GADD, C. J. (2011). The Agricultural Revolution in Sweden, 1700-1870. In J. MYrDAL \& M. Morell (Eds.), The Agrarian History of Sweden. Lund: Nordic Academic Press. Grantham, G. W. (1980). The Persistence of Open-Field Farming in Nineteenth-Century France. The Fournal of Economic History, 40 (3), 515-31.

GRÜNE, N., HÜBNER, J. \& SIEGL, G. (Eds.) (2016). Rural Commons: Collective Use of Resources in the European Agrarian Economy. Inssbruck: Studien.

Hansson, B. (1992). How the Land is Used. In Å. Clason \& B. Granström (Eds.), National Atlas of Sweden: Agriculture. Stockholm: SNA.

Healey, J. (2016). Co-operation and Conflict: Politics, Institutions and the Management of English Commons, 1500-1700. In N. GrÜNE, J. HüBNER \& G. SIEGL (Eds.) Rural 
Commons: Collective Use of Resources in the European Agrarian Economy. Inssbrug: Studien.

HeCKSCHER, E. F. (1941). Svenskt arbete och liv: Från medeltiden till nutiden. Stockholm: Bonnier.

HeLmFRID, S. (1961). The Storskifte, Enskifte and Laga Skifte in Sweden: General Features. Geografiska Annaler, 43 (1-2), 114-29.

HoFFMAN, P.T. (1989). Institutions and Agriculture in Old-Régime: France. Fournal of Institutional and Theoretical Economics (FITE) / Zeitschrift für die gesamte Staatswissenschaft,145 (1),166-81.

JANsson, U. (1998). Odlingssystem iVänerområdet: En studie av tidigmodernt jordbruk $i$ Västsverige. PhD thesis. Stockholm: Stockholms universitet.

McCloskey, D. N. (1975). The Economics of Enclosure: A Market Analysis. In W. N. PARKER \& E. L. Jones (Eds.), European Peasants and Their Markets: Essays in Agrarian Economic History. Princeton: Princeton University Press.

Moor, T. DE (2009). Avoiding Tragedies: A Flemish Common and Its Commoners under the Pressure of Social and Economic Change during the Eighteenth Century. Economic History Review, 62 (1), 1-22.

NySTRÖM, L. (2007). Att göra omelett utan att slå sönder ägg: Skiftesvitsordets teori och praktik: laga skifte i Fyrunga 1844. In L. A. PALM \& M. SJöBERG (Eds.), Historia:Vänbok till Christer Winberg. Göteborg: Göteborgs universitet.

Olsson, M. \& Svensson P. (2010). Agricultural growth and institutions: Sweden, 17001860. European Review of Economic History, 14 (2), 275-304.

Ostrom, E. (1990). Governing the Commons: The Evolution of Institutions for Collective Action. Cambridge: Cambridge University Press.

Pettersson, R. (1983). Laga skifte $i$ Hallands län, 1827-1876: Förändring mellan regeltvång och handlingsfrihet. Stockholm: Stockholms universitet.

PetTERsson, R. (2003). Ett reformverk under omprövning: Skifteslagstiftningens förändringar under första hälften av 1800-talet. Stockholm: Kungliga Skogs- och Lantbruksakademien.

Renes, H. (2010). Grainlands: The Landscape of Open Fields in a European Perspective. Landscape History, 31 (2), 37-70.

SHAW-TAYLOR, L. (2001). Labourers, Cows, Common Rights and Parliamentary Enclosure: The Evidence of Contemporary Comment c. 1760-1810. Past E Present, 171 (1), 95-126.

Skaraborgs Läns hushållnings sällskaps tidning (1852). Skara: Skaraborgs läns hushållningssällskap.

SvENSSON, H. (2005). Öppna och slutna rum: Enskiftet och de utsattas geografi: Husmän, bönder och gods på den skånska landsbygden under 1800-talets första hälft. Lund: Lunds universitet. 
Svensson, P. (2006). Peasants and Entrepreneurship in the Nineteenth-Century Agricultural Transformation of Sweden. Social Science History, 30 (3), 387-429.

SöDerström, M. \& PiIKki, K. (2016). Digitala åkermarkskartan: Detaljerad kartering av textur $i$ åkermarkens matjord. Skara: Sveriges Lantbruksuniversitet. (Interactive soil texture map available at https://www.sgu.se/samhallsplanering/planering-och-markanvandning/markanvandning/jordbruk-skog-och-fiske/lerhaltskartan-digital-akermarkskarta/)

Thompson, E. P. (1963). The Making of the English Working Class. London: Gollancz.

Turner, M. E. (1980). English Parliamentary Enclosure: Its Historical Geography and Economic History. Folkestone: Archon Books.

Wiking-Faria, P. (2009). Freden, friköpen och jörnplogarna: Drivkrafter och förändringsprocesser under den agrara revolutionen i Halland, 1700-1900. PhD thesis. Göteborg: Göteborgs universitet.

WinberG, C. (1990). Another Route to Modern Society: The Advancement of the Swedish Peasantry. In M. Lundahl \& T. Svensson (Eds.), Agrarian Society in History: Essays in Honour of Magnus Mörner. London: Routledge.

Yelling, J. A. (1977). Common Field and Enclosure in England, 1450-1850. London: MacMillan. 